\title{
Currency crisis and external fragility: a Minskyan interpretation applied to the Brazilian economy between 1999 and 2013
}

Crises cambiais e fragilidade externa: uma interpretação minskyana aplicada à economia brasileira entre 1999 e 2013

Victor Hugo Rocha Sarto

Universidade Estadual Paulista "Júlio de Mesquita Filho"

Luciana Togeiro de Almeida

Universidade Estadual Paulista "Júlio de Mesquita Filho"

\section{Resumo}

\section{Abstract}

This work has two goals. The first one is to develop an interpretation for open economies founded on Minsky's financial fragility hypothesis about the process of a currency crisis and its determinants. The deterioration of an economy's external financial structure is identified as the reason for the increase of its crisis susceptibility. With this approach, we create external fragility indexes intending to measure an economy's crisis susceptibility. Our second objective is to evaluate the Brazilian external fragility between 1999 and 2013 using the index and the interpretation previously developed. The results suggest that Brazilian's external fragility suffered a gradual and significant decrease and tends to follow stable trend in the coming years.

\section{Keywords}

Minsky; currency crisis; external fragility; Brazilian economy.

JEL Codes F31; F32; F34; F40.
Este trabalho possui dois objetivos. O primeiro é desenvolver uma interpretação sobre o processo gerador de crises cambiais e seus determinantes, tendo como base a hipótese de fragilidade financeira de Minsky. A deterioração da estrutura financeira externa de uma economia é identificada como o fator responsável por elevar sua suscetibilidade a crises cambiais. A partir desta interpretação, são construídos indicadores de fragilidade externa visando mensurar a suscetibilidade de uma economia sofrer uma crise cambial. O segundo objetivo deste estudo é avaliar a evolução da fragilidade externa da economia brasileira entre 1999 e 2013 por meio da aplicação dos indicadores e da interpretação desenvolvidos na primeira parte do trabalho. Os resultados sugerem que a fragilidade externa brasileira sofreu gradual e significativa redução e tende a seguir trajetória estável nos próximos anos.

\section{Palavras-chave}

Minsky; crises cambiais; fragilidade externa; economia brasileira.

Códigos JEL F31; F32; F34; F4O. 


\section{Introduction}

In the last thirty years, currency crisis has become a frequent phenomenon in both developed and emerging nations, with effects that have been gaining more power to generate damages in the financial and production systems of these nations, and a growing potential of global contamination. (Arestis; Paula, 2008; Griffith-Jones; Ocampo; Stiglitz, 2010).

For these reasons, studies dedicated to measure the tendency for countries to suffer with currency crisis have earned the spotlights in the literature, especially after the 2008 international crisis.

In Brazil, the debate about the national external fragility can be divided, generally speaking, in two opposing strands. On one side, there are arguments in defense of the proposition that the Brazilian economy acquired, in the last decade, a bigger resistance to currency crisis. This would be the result of structural and macroeconomic reforms adopted since 1994, an appropriate management of macroeconomic policy and a quality external insertion before a global economy with a new setting to the country.

These factors made the external account more solid, especially with commodities external trade and better access to external funding, with the high influx of long-term investments attracted by omit domestic dynamism, macroeconomic soundness and the country's credibility earned with the international market. (Barros, 2008a; 2008b; Franco, 2008; Lacerda, 2009; Coutinho, 2010; BCB, 2013a).

Generally, defenders of this proposition lean their arguments on the combination of three evidences: the improvement of traditional indexes of foreign debt since 1999; the sharp drop movement of the risk-Brazil from 2003 and obtaining investment grade rating by international agencies since 2008; and the unprecedented ability demonstrated by the country in resisting the turbulence generated by the international crisis of 2008, when the economy experienced a modest decline in Gross Domestic Product (GDP) in 2009, with rapid recovery in 2010 (Prates; Cunha; Lélis, 2011; BCB, 2013a; 2013b).

The second strand defends that the country presents high external fragility, pronounced in recent decades by the commercial and financial liberalization process. From this point of view, the above evidence is insufficient, for reflecting the improvement of the external conjuncture situation of the economy only, ignoring its most relevant aspect, its structural external fragility. It 
translates the capacity for long-term resistance of the country, expressed by specific features, such as the productive structure ${ }^{1}$, foreign trade standard, systemic efficiency, technological dynamism and financial and institutional strength (Carneiro, 2010; Carcanholo, 2010; Gentil; Araújo, 2012).

For this line of argument, the assembly of these structural features, in Brazil, produces a pattern of poor external insertion manifested in three ways. First, with the tendency to Current Account (CA) deficits. Second, the deterioration of the composition of foreign debts by the increasing share of short-term capital and high liquidity. And third, the high volatility of exchange rates and interest rates. To its proponents, the international crisis of 2008 made clear the high Brazilian external fragility, given the clear manifestation of these three sets of factors after its advent (Gonçalves, 2012).

This work aims to contribute to the literature about currency crisis, and to the empirical debate about the recent evolution of Brazilian external fragility in two ways. First, we elaborate on an interpretation for open economies of the financial fragility hypothesis, of Minsky, about the generating process of these crises and their determinants. To fulfill this goal, the author's ideas are brought to the reality of international economy. The quantitative and qualitative deterioration of external wealth of an economy is identified as the factor responsible for raising its susceptibility to currency crises, when affecting international funding conditions available for the fulfillment of its commitments to non-residents.

Based on this interpretation, external fragility indexes are constructed to cover as much cyclical and short-term features of a country's external sector, comprehended in the results of its Balance of Payments (BOP), as the structural and long-term features manifested in the composition of its debts and foreign assets.

Our second goal consists in assessing the Brazilian external fragility between 1999 and 2013 by the application of the indexes and the interpretation previously developed to that referred country.

This work is structured in three other sections besides this introduction. Section 2 is dedicated to the theoretical study proposed in the first goal. In section 3, the evolution of Brazilian external fragility is evaluated. Finally, for the conclusion, in Section 4, are woven some concluding remarks.

1 In this line of research, there are growth models with restriction on BOP, which relate domestic productive structural problems to the external sector of the economy. About this line of research, see Smith (2012). 


\section{The financial fragility hypothesis of Minsky and the external sector of national economies}

This section aims to develop an interpretation for open economies of the financial fragility hypothesis of Minsky about the generating process of currency crisis and its determinants.

For that, initially, we work with some basic concepts of the financial fragility hypothesis (2.1). In the following subsection (2.2), the concept of external fragility and the Minskyan interpretation proposed by this work are developed. From that, we build two general indexes of external fragility, and they unfold in two other specific indexes, the first one cyclical and, the second, structural, described, respectively, in omit subsections 2.2.1 and 2.2.2.

\subsection{Financial fragility hypothesis}

Minsky (2010) develops the concept of financial fragility as a measure of the capacity of an economy to face shocks in financing conditions without a widespread dislocation of payment flows between agents. This definition comes from the notion of fragility as a result of the set of features of the financial structures of units comprising the economy, generically defined by (Tonveronachi, 2006, p. 24):

According to Minsky, every economic unit is characterized by a set of features inherited from the past, possessing significant degrees of rigidity. This inheritance may be summed up as consisting, on the one hand, of the stocks of physical, financial and immaterial capital, and on the other side, of contractual obligations, among which is a given debt structure. The various forms of capital are the source of future expected incomes (here considered net of the costs necessary to sustain the position), while the debt is the source of financial outflows.

The financial structure of a unit is a consequence of its historically accumulated cash flow result, which can be expressed by the following equation (ibid.):

$$
\begin{aligned}
& Y_{n i}+Y_{f i}+\Delta L_{i-1} \leq \geq r_{i} D_{i-1}+M D_{i} \\
& i=1, \ldots, n
\end{aligned}
$$

where, $Y_{n}$ is net operating revenue (quasi-rents);

$Y_{f}$ are the net returns from owing financial assets; 
$L$ are net assets that are held in excess within normal operations; $r$ is the interest rate that affects debts $D$; and $M D$ are expenses with $D$ amortizations.

The values obtained in equation (1) for each period result from the combination of planning and expectation, as economic units operate through the system money-today / money-tomorrow. Money-today, obtained to finance the purchase of goods or activities, must be validated by future income expected from the ownership of these assets, which, in turn, depends on the performance of the unit and the economy.

Therefore, whenever operating income and net returns from the ownership of assets exceed the interest expenses and amortization of assumed debt, the unit is in a liquid position, with surpluses and accumulation of new assets. When the opposite occurs, the situation of illiquidity requires the sale, with the corresponding value, of stocks from previously accumulated assets or the acquisition of new loans in the financial market.

The capacity of a unit to sustain its financial structure for each period is defined by its solvency positions, expressed by the equation (2) (ibid.):

$$
N C_{i}=K_{i} Y+L_{i}-K_{i} D
$$

where, NC is the net value of the forms of capital;

$K Y$ is the present value of the expected total net gains (quasi-rents); and $K D$ is the present value of the forms of debt.

The unit is in its solvent position while NC is positive, a situation which depends on the terms of financing offered by the markets, which, in turn, vary depending on the expected return on assets of this unit. According to Minsky (2010, p. 284), "[...] prospective profitability of collections of capital assets under the control of a firm is critical in determining investment, for it determines whether the production and ownership of capital assets are financed".

Capital assets are valuable because they generate profits. So, its market price and the interest of agents in acquiring it, enabling the financing and the solvency position of the respective unit which owns them, reflect the present expectations on future profits and how these profits are transformed into present values. 
In this sense, a unit becomes insolvent when its structure cannot be funded neither by internal nor by external borrowing resources, given the unwillingness of markets in financing structures in which prospective profitability, costs and risks produce the expectation of not receiving the expected returns over the values applied. This results in a cash flow crisis at the unit and is a key-element for understanding the process of unleashing financial instability in capitalist economies ${ }^{2}$.

The characteristics of the financial structures of the units, defining their liquidity and solvency status, depend on the financial arrangements adopted by them. The Minskyan taxonomy defines three types of schemes: hedge, speculative and Ponzi.

Units that use hedge financing: "[...] expect the cash flow from operating capital assets (or from owning financial contracts) to be more than sufficient to meet contractual payment commitments now and in the future" (ibid., p. 287).

Hedge positions are subjected only to operational risks. Difficulties to honor their debts might result from a revenue decline or increased costs in relation to what was expected ${ }^{3}$. Thus, their safety margins are sufficient to ensure the liquidity position at all times.

Units using the speculative financing: "[...] expect the cash flows to the unit from operating assets (or from owning financial contracts) to be less than the cash payment commitments in some, typically near-term, periods" (ibid., p. 287).

Speculative positions are subjected to both financial and operational risks. These units expect their receipts in periods subsequent to the initial phase of illiquidity to exceed their acquired obligations. In the meantime, the funds to pay off outstanding debts come from refinancing. The conditions offered by the markets in the contract of these new debts influence the future payments and, therefore, unexpected changes in them can turn illiquidity into insolvency, depending on the unit's safety margins. The size of these margins also affect the financing conditions, as they influence risk and return expectations of investment projects.

2 In Minsky's words (1982b, p. 13): “[...] the critical element in explaining why financial instability occurs is the development over historical time of liabilities structures that cannot be validated by market-determined cash flows or asset values."

3 By equation (1), this means that the values of $\mathrm{r}$ and $\mathrm{L}$ are predetermined. The first two because the contracts are set at fixed interest rates and the latter because its value is independent of the prices of financial markets. 
Finally, units using Ponzi financing (ibid., p. 288):

[...] for at least some near-term periods, the cash payment commitments on income account exceed the expected cash payment receipts on income account. [...] for Ponzi finance units financing costs are greater than income, so that the face amount of outstanding debt increases.

Ponzi positions are the most vulnerable to financial market conditions, because they need to refinance their positions more frequently. Unfavorable changes in the pattern of payment terms or on credit standards offered by the markets more easily undertake the feasibility of this type of financial arrangement (ibid.).

The evolution of financial structures towards fragilization depends on opportunities and profit expectations that induce the use of riskier financial arrangements, which boost the capital gains, the pace of investment and thus the expansion of the economy.

Financial institutions, also motivated by optimism about profits, react to this process validating agents' decisions of becoming increasingly involved in these schemes, by creating new sources of funding. Indeed, it creates the conditions for development of a euphoric economy.

The resulting investment boom overloads the national financial system by speculative and Ponzi schemes, which increase the amount of investments financed by loans, expanding the share of debt in the financial structure of the units, and drive the market for loans based on the exchange of long-term debt for short-term financing of ownership of assets and investments maturing. In other words, banks and companies are induced to a higher debt in the short term on favorable expectations about the ways the economy will behave (Minsky, 1982a; 2010).

The fragilization becomes unstable before the mismatch between supply and demand for funding on the economy, due to the rate of expansion of higher demand to supply. In a down economy, the growth of the risks of lenders and borrowers modify expectations about the ability of investments to generate the expected profits and, therefore, bankers and their clients alter the structure of obligations deemed acceptable for the financing of positions in capital assets. Thus, uncertainty about the future of the economy lead markets to restrict the means of financing and customers to retain currency by refusing to purchase less liquid assets, preventing risky financial practices (Minsky, 1982a). 
In this scenario, the units see their ability to validate obligations dispelled, being forced to liquidate their capital assets. Therefore, a general fall in the value of these assets starts to derail new investments and profits, leading the economy to a financial crisis.

\subsection{The financial fragility hypothesis in open economies: the exter- nal fragility}

The biggest contributions of Minsky are from studies of closed economies, although the author himself considers the importance of interpretations, from his approach, to open economies (Arestis; Sawyer, 2000). Indeed, several studies have sought to use such an approach to understanding the causes of currency crises, especially in developing countries (Gray; Gray, 1994; Lopez, 1997; Dymski, 1998; Paula; Alves Jr., 1999; Arestis; Glickman, 2002; Kregel, 2004; Tonveronachi, 2006; Resende; Amado, 2007).

Relations between economic agents acquire greater complexity in an open environment. The solvency position of units that relate to foreigners, whether countries or active members of an economy, is not only related to its ability to honor its commitments, but to its ability to generate foreign debts to enable this payment, a problem that has a macroeconomic nature and transcends the issue of vulnerability analysis in the individual project (Resende; Amado, 2007). Under these conditions, international creditors observe both the project cash flow as what they perceive as the external vulnerability of the country on the availability of hard currency and, from there, establish their offer of resources and define the required profitability (Correa; Mollo; Biage, 2008).

Similar to the concept applied to the closed economy, the external fragility comes from the financial structures of the units that compose an open economy and maintain relations with foreign countries. The results of these interactions, historically accumulated, define the external wealth of the economy by the formation of stocks of assets and debts in foreign currency. Thus, the external sector of a country can be understood as a single economic unit, where BOP is its cash flow and external wealth defines its financial structure.

As in any unit, the shaping of its financial structure is influenced by the characteristics of the economic system in which it is inserted. In this par- 
ticular case, cyclical and structural changes in the domestic economy and the international system are reflected on the external financial structure of the evaluated country.

At the same time, the characteristics of the above structure provide rigidity for its operation. The degree of rigidity of this structure varies according to the degree of external fragility:

External vulnerability [or external fragility] means a low resilience of national economies facing destabilizing pressure factors or external shocks. The vulnerability has two equally important dimensions. The first involves the response options with the policy instruments available, and the second incorporates coping or adjustment costs in the face of external events (Baumann; Canuto; Gonçalves, 2004, p. 229).

In other words, the external fragility is the ability of a country to sustain its external financial structure in time without a generalized disarticulation of BOP flows. The difficulties in that vary according to its potential to raise the funds needed to meet its commitments to non-residents, a feature related to the size and composition of its financial structure, which determine its degree of sensitivity to the financing conditions offered by international markets for rolling its debts.

The balance of the external sector is ensured whenever the total demand for foreign currency is met by an offer at least equivalent to BOP's requirements in each period. Instabilities in BOP result from a process in which the external financing offer is insufficient to meet a demand generally expanding. This is a situation which features the problem of Minsky's fragility financial hypothesis (2010) on the BOP of a country.

According to Mollo (1988, p. 108) "The problem for Minsky is nothing more than a demand problem of financing means increasing in the face of an inelastic supply of financing.". Thus, the inability to raise sufficient amounts of resources to meet demand is the factor responsible for triggering instabilities and crises in the external sector of the economy.

As it turns out, if the maintenance of this structure cannot be financed by the foreign exchange generated in the economy itself, its units may resort to foreign financing. The availability of these funds depends on the subjective preferences of the agents in the external financial markets, defined in terms of their expectations on profit opportunities in the economy and the solvency condition of its external sector. Such expectations are constructed and influenced by cyclical and structural features of the economy and assessed by exogenous factors. In other words, in forming 
their expectations of an economy, the agents consider all those domestic and international elements that affect or may affect the risk return ratio expected from the acquisition or financing of assets in it. Admitting Minsky's argument about money supply endogenously determined by markets, through financial innovations, we have that, while investor optimism about BOP's ability to produce expected foreign exchange persists, there will be no restrictions on the supply of financing, even in the face of an expanding demand.

Initially, as suggested by equation (2) applied to our analytical model, in periods of high confidence of foreign investors on the present value of the expected returns of their investment in a country, the BOP refinancing of the latter by foreign capital lies assured and thus the balance between supply and demand for foreign exchange is guaranteed.

By this interpretation, the mismatch between supply and demand for the amount of foreign currency needed to balance the BOP accounts results from changes in the subjective preferences of their foreign financiers. The degree of optimism of these agents should deteriorate due to the growth of external fragility of the reporting country, especially when associated with any domestic or international disturbing event capable of arousing their suspicion on this economy.

Greater external fragility changes the expectations of the agents involved in the financing of $\mathrm{BOP}$ because, before the worsening of the solvency condition of the external sector, the lender's and debtor's risks rise while the return prospects on capital are reduced in this country. The result is a worsening of financing conditions in terms of costs and availability of funds, just as the deteriorating external financial structure demands foreign refinancing in larger quantities. Hence, as it decreases the country's ability to sustain its external accounts, the BOP imbalances become more likely and their real and financial consequences tend to be bigger. The latter can manifest through capital flight, macroeconomic instability and, ultimately, by currency crises.

Our interpretation of the generating process of instability and crisis in $\mathrm{BOP}$ justifies the importance of studies dedicated to measuring the external fragility of economies. For this purpose, Paula and Alves Jr. (. 1999, p 79) created an external fragility index (EFFI):

We can define, from the information on the balance of payments of a country, the degree of external financial fragility; the larger (or smaller) are the needs of 
an economy that has to resort to the international financial market to renegotiate open financial position (that is to say, that cannot be immediately paid), even if with unfavorable interest rates and terms.

For open financial positions, the authors understand those obligations they named as real and virtual, present at each period:

Real payment obligations reunite expenses with imports and services plus the loan repayments. Virtual obligations include stocks of short-term capital and portfolio investments [...] These obligations may be "faced" through reserves, export revenues (interest and other services), medium and long term loans and direct investments (ibid., p. 79).

EFFI measures the real and potential needs of an economy to renegotiate its financial external open positions by the ratio between their immediate obligations, or short-term, and the foreign exchange available to meet them. Its calculation is performed by the equation:

$$
\begin{aligned}
& E F F I=\left(M+D_{j}+D_{O S}+A+C S T_{-1}+P L A_{-1}\right) / \\
& \left(X+R_{j}+R_{O S}+R E_{-1}+I_{d}+E_{m 1}\right)
\end{aligned}
$$

where, $M=$ imports;

$X=$ exports;

$D=$ expenses with interest "j" and other services (OS);

$R=$ revenue with interest "j" and other services (OS);

$A=$ loan repayments

$C S T_{-1}=$ stock of short-term capital, outdated by one period;

$P L A_{-1}=$ stock of liquid investment in portfolio, outdated by one period;

$R E_{-1}=$ international reserves accumulated until the previous period;

$I_{d}=$ foreign exchange input corresponding to direct investment;

$E_{m 1}=$ medium and long term investments.

The higher the index, the lower the country's ability to meet the most immediate external financial commitments, which puts it in a situation of greater dependence on foreign refinancing ${ }^{4}$, increasing their propensity to be affected by changes in the international environment that alter the external financing conditions.

That way, EFFI works as a tendency indicator that seeks to assess the

4 By the interpretation developed along this work, an economy's bigger or smaller dependence on foreign refinancing is not only the result of its CA balances. As demonstrated by equation (3), it is also associated with the financial account influxes and to the external assets and debts stocks of the country. 
increase or decrease the importance of the subjective evaluations of agents that hold rights and/or obligations in foreign currency in determining the outer frame of the economy (ibid.).

This interpretation allows a rank for financial position assumed by a country on its external accounts similar to the one developed by Minsky. The country assumes a hedge position whenever the most immediate financial commitments are compatible with current revenues, the long-term liabilities and reserve assets available. In turn, the position is speculative or Ponzi if real and potential financial commitments with nonresidents exceed their ability to pay. In the latter case, foreign capital attraction policies become necessary to ensure the balance of BOP, subjecting the economy, largely, to the absorption of speculative flows (ibid.).

The great accomplishment of EFFIlies in the fact of it being able to assess, jointly, the two aspects of the financial structure described by Minsky (2010) able to modify their level of fragility, namely, the amount of current expenditure by the revenue generated each period and the quality of the acquired refinancing that composes its liability structure in relation to the forms of capital available. It is, thus, a measure that considers size and composition of the forms of capital in relation to forms of foreign debt of a country.

As one of the contributions of this work, it is intended to complement the study of Paula and Alves Jr. (1999), analyzing separately, in the following subsections, the two aspects covered by the index. Thus, the goal is to identify the importance of each aspect to the weakening of the external sector of the economy, justifying the aggregate results found in EFFI.

Finally, it was argued in this subsection that the degree of external fragility affects the relationship between demand and supply of foreign funds made available to the economy, the size and frequency of the imbalances in the flows of its BOP and its shock resistance capacity. Such dislocations of financial flows are crucial for Minsky's analysis because they illustrate the key moments of the business cycle where the fragility turns into instability and, potentially, into crisis.

Indeed, we adapt an index capable of measuring the three aforementioned implications, through the ratio between total outflows and foreign exchange input of the economy in each period. This index of current external fragility (current EFFI) is calculated by the method proposed by Martins (2007) and Lacerda and Oliveira (2009): 


\section{Current EFFI $=\sum D E C M E / \sum D I C M E$}

where, $D E C M E=$ Current demand for resources in foreign currency;

$D I C M E=$ Current availability of resources in foreign currency.

Current EFFI values higher than one indicate instability moments for external accounts, where demand exceeds availability of resources in foreign currency.

According to the interpretation developed in this subsection, the convergence between the two fragility in dices presented here is expected. Moments of greater deterioration of the external financial structure of a country should correspond to moments of mismatch between demand and supply of foreign exchange, greater instability of BOP flows and lower resilience of the external sector to shocks. This relationship is evaluated in subsection 3.2.3.

\subsubsection{Operational external fragility: current accounts and net foreign debts}

By operational external fragility, we understand the one that arises from changes on dimensions of capital and/or debt forms of the external financial structure of an economy, that is to say, of quantitative changes in its net foreign wealth.

In an analysis of BOP flows of a country, the behavior of its net foreign debts (NFD) can be assessed in terms of CA results ${ }^{5}$ (Tonveronachi, 2006):

$$
N F D-N F D_{-1} \equiv-(C A) \equiv-N X-N F I-U T
$$

where, $C A$ is Current Account,

$N X$ is net exports of goods and services;

NFI are net revenues of foreign assets and debts;

and UT are Unilateral Transfers.

5 Strictly speaking, the variation of NFD does not depend only on BOP flows. Other factors influence their size, such as changes in the market value (price) of assets and debts stocks and their expression in dollars (parities), the latter being directly impacted by variations in nominal exchange rate (BCB, 2008). 
By the equation (5), CA deficits increase NFD in the same proportion (ibid.).

CA result define the liquidity position of an economy in foreign currency in each period. Illiquidity at one point indicates that, in the local exchange market, foreign currency revenues of a country are lower than its compensation expenses of foreign debts.

Successive periods of illiquidity can be sustained indefinitely, provided there is sufficient supply of foreign funds to cover the service of foreign debts and other debts generated in the capital and financial account, ensuring the overall closure of BOP's accounts. The financing offer persists as long as there is the expectation that, in the future, illiquidity will revert to ensure creditors expected return.

The expression (5) can be modified and extended, allowing a more precise definition on liquidity and solvency positions of an economy compared to the rest of the world (ibid.):

$$
\begin{aligned}
& N X_{j}+r_{j}^{F A} F A_{j-1}+U T_{j}+\Delta F R_{j} \geq \leq r_{j}^{F A} F D_{j-1}+M D_{j} \\
& i=1, \ldots, n
\end{aligned}
$$

where, $r^{F A}$ is the return rate for foreign assets $F A$;

$F R$ is the variation in international reserves, used to temporarily smooth the illiquidity of the external sector;

$r^{F D}$ is the interest rate of foreign debts $F D$, or, more broadly, the costs of remuneration of capital that compose this liability; and $M D$ is the debt generated by the amortization of debts in their due date phase.

The country is in liquidity position when the current revenue from net exports, the net income from the ownership of foreign assets and unilateral transfers are sufficient to honor the $\mathrm{r}^{\mathrm{FD} F D}$ payment. The rest of the expenses $(\mathrm{MD})$ can be refinanced with international markets. In the process of refinancing, changes in the conditions offered by the markets affect CA from the following period by $\mathrm{r}^{\mathrm{FD}} \mathrm{FD}$.

With the concepts to identify the operational fragility of a country's external sector developed, now follows the interpretation of them, according to Minskyan taxonomy. Table 1 contains the criteria used to classify 
financing regimes, defined according to the behavior of CA and NFD in the medium and long term perspectives:

Table 1 Classification criteria of financing regimes

\begin{tabular}{l|l|l|l}
\hline Country Position & NFD & Characteristics & Safety Margins \\
\hline Hedge & Zero. & $\begin{array}{l}\text { CA balanced, } \\
\text { with small and } \\
\text { temporary deviations. }\end{array}$ & $\begin{array}{l}\text {-International Reserves; } \\
\text { - Monetary and Fiscal Policy; } \\
\text { - Prudent evolution of NX. }\end{array}$ \\
\hline Speculative & Positive, butstable. & $\begin{array}{l}\text { Current revenue suf- } \\
\text { ficient to remunerate } \\
\text { foreign debts: } \\
\text { CA in balance. }\end{array}$ & $\begin{array}{l}\text {-International Reserves; } \\
\text { - Monetary and Fiscal Policy; }\end{array}$ \\
\hline $\begin{array}{l}\text { Ponzi } \\
\text { Sustainable }\end{array}$ & $\begin{array}{l}\text { Positive and growing, } \\
\text { but at a small and } \\
\text { constant rate. }\end{array}$ & $\begin{array}{l}\text { Current revenue insuf- } \\
\text { ficient to remunerate } \\
\text { foreign debts: } \\
\text { constant deficit in CA. }\end{array}$ & - International Reserves; \\
\hline $\begin{array}{l}\text { Ponzi } \\
\text { Unsustainable }\end{array}$ & $\begin{array}{l}\text { Positive and growing } \\
\text { at increasing rates. }\end{array}$ & $\begin{array}{l}\text { Current revenue insuf- } \\
\text { ficient to remunerate } \\
\text { foreign debts: } \\
\text { constant deficit in CA. }\end{array}$ & None. \\
\hline
\end{tabular}

Source: Elaborated from Tonveronachi (2006).

An economy finds itself in a hedge position when it is capable of maintaining NFD zero and, hence, CA in balance. Small and temporary deviations from this balance are natural and can be administrated by exchange reserve policy combined with small adjustments in fiscal and monetary policies. The latter, by modifying the growth pace of domestic income, are capable of rebalancing CA by their effects over NX. The prudent evolution of NX is considered another important safety instrument of a country.

In the speculative position, NFD is positive, but stable, and CA is in balance. In this condition, a more expressive volume of NX is necessary to pay the most meaningful expenses with debts revenue and prevent deficits in CA. Furthermore, the refinancing of debts repayments in the maturation phase and other debts generated by NFD depends, to a greater extent, on external resources. About the safety margins, restrictive fiscal and monetary policies, the accumulation of reserves and prudent evolution of $\mathrm{NX}$ are able to contain any imbalances in CA, however, the effectiveness of these interventions tends to be lower than in hedge position, due to the greatest dimension of these imbalances facing shocks. 
The Ponzi position is characterized by the successive incapacity of the economy to generate revenues in an amount sufficient to pay the debts, which implies deficits in CA and thus positive and expanding NFD. In this regime, the unit is dependent on an increasing supply of refinancing to ensure the balance of BOP. This position is divided between sustainable and unsustainable (ibid.). The country is classified as sustainable Ponzi if it is able to keep a small and steady growth pace in NFD. For this, revenues, particularly NX, must have the same rate of growth of expenditure on compensation of NFD. Restrictive actions of monetary and fiscal policy are no longer effective to contain the most significant imbalances in CA. High stock reserves and prudent evolution of NX are the safety margins of this position.

When NFD expansion occurs with increasing rates, Ponzi position is classified as unsustainable. Its fast deterioration, provides that it persists in medium and long term, should eliminate the efficacy of all its safety margins. In this process, market expectations about the solvency condition of the unit suffers a gradual deterioration, making it difficult to refinance to the extent that access to foreign funds is made impossible, at which time their total discredit to the creditors makes default an inevitable consequence.

\subsubsection{External structural fragility: foreign financing quality and exter- nal financial structure composition}

By structural external fragility, we understand the one that arises from changes in the composition of capital and/or debt forms of the external financial structure of an economy, that is to say, of qualitative changes in its net foreign wealth, defined in terms of degree of liquidity ${ }^{6}$, and maturation time of the capital that composes it.

In an open economy, external fragility can be manifested when there are domestic units that finance themselves in foreign currency with lower deadlines than the maturity of the financed project (Paula; Alves Jr., 1999). From the adoption of these speculative arrangements stems the increase in shortterm obligations for readily available assets and, therefore, for the degree of liquidity of foreign debts in relation to that of national foreign assets. 
Kaltenbrunner and Paincera (2009) point out that Minsky introduced the concerns regarding the composition of the financial structure of the units in the analysis of Keynesian liquidity, showing how changes in qualitative aspects of these structures increase the risks to which the units are submitted before the investors' portfolio allocation decisions:

According to Minsky, however, capital asset pricing and portfolio decision theo-
ries should take into account the debts positions of economic units, which are
interrelated with their assets positions as "... a portfolio decision has two inter-
dependent facets. The first relates to what assets are to be held, controlled, or
acquired; the second relates to how the position in these assets - i.e., their owner-
ship or control-is to be financed" (Minsky, 1975: 70) (ibid., p. 3).

Following this line, several authors associate the accumulation of shortterm or highly liquid foreign exchange to the expansion of external. These capitals with high potential for reversion require recipient countries to a constant search for refinancing among foreign markets to offset their destabilizing effects, real and potential, on the external accounts and on the economy as a whole. The need of foreign investors to relocate their portfolios can generate a liquidation process of household assets, motivated by factors that can even be fully unharnessed from the local economic situation (Paincera, 2009; Paula; Alves Jr., 1999; Correa; Mollo; Biage, 2008; Corrêa; Munhoz; Pereira, 2012).

For a study based on Minsky, to measure the "weight" of capital with speculative profile in the composition of the financial structure of any unit requires the consideration that their liability positions are interrelated to their active positions. In other words, it makes sense to evaluate the external fragility of a country considering only the highly liquid stock present in their debt forms, because the importance of the latter can only be estimated when it is related to the forms of capital available for the unit.

To measure the external structural fragility of an economy, this work evaluates the components of its external wealth, according to its degree of liquidity defined in Corrêa, Munhoz and Pereira (2012, p. 3)':

[...] we regard as capital flows "with short-term bias,"those which have a great potential for rapid reversion. They are: Investments in Portfolio (Equity and Fixed Income Securities, short-term and long term), the Currency and Deposits, shortterm Loans to Suppliers, short-term Loans in general, and Derivatives.

7 This classification is based on empirical tests applied to emerging economies, including Brazil between 1995 and 2010. Besides this study, Correa's works, Mollo and Biage (2008) and Munhoz, Kobayashi and Correa (2010), also applied to emerging economies and Brazil, found similar results. 
This group of capitals represents the external wealth component of a country, with direct and immediate impact on their external structural fragility ${ }^{8}$. However, we should also consider some of their peculiarities, especially when it comes to short-term foreign assets.

Faced with a currency crisis, the aversion to risk behavior, distinctive of these capitals, should produce a flight from these passive positions abroad and the permanence of these private active positions in foreign markets ${ }^{9}$, where they already were. Hence, the country cannot count on its private resources invested abroad, but only on its reserve assets under the control of the monetary (Gentil; Araújo, 2012).

The importance in considering the reserve assets in the analysis of external structural fragility lies in the fact that, in the formation of expectations of foreign investors, a relevant indicator they consider is the stock of hard currency readily available to meet the current and emergency obligations and ensure the stability of the exchange rate $e^{10}$.

Thus, in our Minskyan perspective, the deterioration of the composition of the external financial structure of a country occurs through the growth of its obligations or debts with "short-term bias" in relation to its assets of immediate liquidity:

$$
\text { External Structural Fragility }=\frac{\text { Short }- \text { Term Liabilities }}{\text { Reserve Assets }}
$$

Results of this measure of fragility allow a rank, in Minskyan terms, of the financial position of an economy external sector. Hedge position occurs when reserve assets overcome short-term debts, a situation in which the country finds itself "covered" on the hypothesis of a massive capital flight abroad. On the other side, whenever the stock of obligations with high reversal potential exceeds the reserves, the country is in a speculative or Ponzi position, a characteristic that increases the odds of getting involved in currency crises.

8 It became evident in the above studies that the other groups of capital that compose the external wealth of an economy are considered capital with long-term bias. Thus, they influence the external weakness only for their effects on flows of BOP.

9 By definition, foreign assets accumulated by private companies in the acquisition of shares do not have immediate liquidity and cannot be used to honor other private agents' commitments.

10 The exchange rate directly affects the external wealth of the country, its ability to generate foreign exchange and return rate on foreign investment. For this reason, its instability tends to negatively influence the formation of expectations of international creditors. 


\section{Brazilian external fragility: a Minskyan interpreta- tion of the period $-1999-2013$}

This section aims to measure the susceptibility to currency crises of the Brazilian economy between 1999 and 2013, through the application of the theoretical and empirical instruments developed in the previous section. Thus, the external fragility is evaluated from an operational point of view (3.1), structural (3.2) and by combining the two previous measures (3.3). Finally, the assessed findings are evaluated in the light of an indicator that seeks to measure the fragility level impact on the external sector of the Brazilian economy ${ }^{11}$.

In order to facilitate the analysis, this time frame is divided into three periods, 1999-2002, 2003-2007 and 2008-2013, according to the behavior of Brazilian external accounts ${ }^{12}$.

\subsection{External operational fragility}

The equation (6), detailed in subsection 2.2.1, is built for Brazil from its $\mathrm{BOP}$ information, according to Table 2:

Table 2 BOP Information to external operational fragility measures

\begin{tabular}{|c|c|}
\hline & Availability of Current Resources \\
\hline NX & $\begin{array}{l}\text { Trade Balance (FOB); } \\
\text { Service Balance }\end{array}$ \\
\hline $\mathrm{r}^{\mathrm{FA} F A}$ & Revenue - Income Account \\
\hline \multirow[t]{2}{*}{ UT } & Current Unilateral Transfers (Net) \\
\hline & Total Demand for Current Resources \\
\hline $\mathrm{r}^{\mathrm{FDFD}}$ & Expense - Income Account \\
\hline MD & $\begin{array}{l}\text { Foreign Direct Investment Debt; } \\
\text { Foreign Portfolio Direct Investment Debt; } \\
\text { Commercial Loan Amortization - LT Suppliers; } \\
\text { IMF Amortization; Amortization of Other regularization operations; } \\
\text { Amortization of Other LT Loans; } \\
\text { Amortization of Loans and Financing - other LT sectors }\end{array}$ \\
\hline
\end{tabular}

11 The data used for the construction of these indicators for Brazil are listed in the Appendix of this work.

12 For an analysis about these three periods, see Prates, Cunha and Lélis (2011). 


\begin{tabular}{l|l}
\hline & Total Demand for Current Resources \\
\hline Other Financial & Brazilian Direct Investment Balance; \\
Account debts * & Brazilian Portfolio Direct Investment Balance; \\
& Other Brazilian Investments Balance; \\
& Derivatives (net); \\
& Currency and deposits (net); \\
& Other LT and ST debts (net) \\
\hline
\end{tabular}

Source: Banco Central do Brasil.Self-Elaboration

* This item measures other components of the financial account of BOP that register debts.

An Figure 1 shows the relationship between current revenues, excluding reserves, and the remuneration costs of foreign debts ( $\left.\mathrm{r}^{\mathrm{FD} F D}\right)$ each trimester between 1999 and 2013. The red vertical bars illustrate periods and dimensions of illiquidity in the external accounts, represented by CA deficits, while green bars show moments of liquidity:

\section{Figure 1 Liquidity x illiquidity of Brazilian external sector}

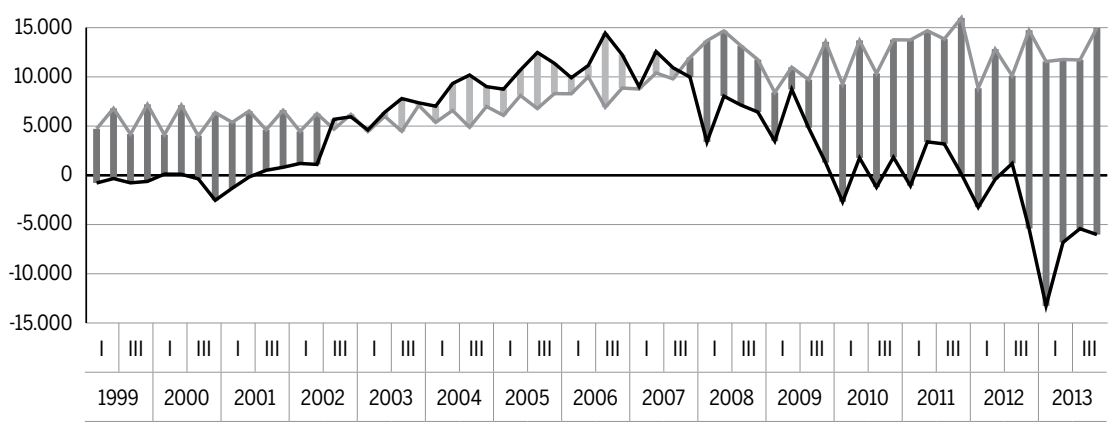

— Debt Remuneration Expenses (US\$ Million) — Current Revenue (US\$ Million)

Source: Banco Central do Brasil. Self-Elaboration.

According to Figure 1, revenues exceeded expenses with the remuneration of the foreign debts only between 2003 and 2007. During this period, NDF decreased ${ }^{13}$. On the other hand, between 1999 and 2002 and between 2008 and 2013 , these costs could not be fully paid with current revenues, moments where the difference had to be covered by foreign refinancing and NFD grew. Therefore, the results suggest that, under the operational perspective, 13 This conclusion is based only in the analysis of liquid credit flows (CA balances) over the country's NFD. 
the external sector of the country presented Ponzi position between 1999 and 2002 and between 2008 and 2013 and speculative from 2003 to 2007. Financing regimes classification continues by analyzing the NFD expansion pace in Figure 2, according to equation (5) described in subsection 2.2.1, and its trend curve:

\section{Figure 2 NFD variation}

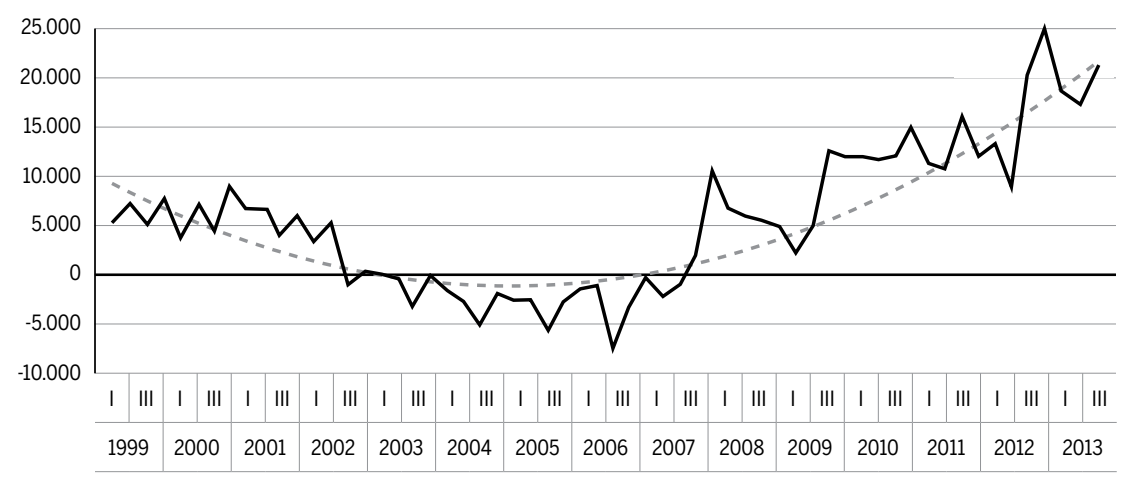

NFD Variation (US\$ Million)

- - - - - Tendency Curve NFD Variation

Source: Banco Central do Brasil. Self-Elaboration.

The behavior of the NFD variation indicates that the operational fragility of the Brazilian external sector followed a cyclical pattern over the period analyzed, in which we can identify three phases. Between 1999 and 2002, NFD has grown, on average, at stable rates, which allows us to qualify the external sector of the country as sustainable Ponzi. From 2003 to 2007, the NFD expansion movement was reversed and fragility was reduced, characterizing a Speculative position. Finally, between 2008 and 2013, the resumption of NFD growth represented a second period of operating fragilization, which occurred, however, at increasing rates, a feature that qualified the external sector as unsustainable Ponzi.

Unsustainable Ponzi position is a warning sign to the country. At any future time, the trend of NFD should be contained, either by voluntary adjustment of the external accounts, through the available action margins, or by an imposing adjustment in the face of its unsustainability, an alternative already experienced by the Brazilian economy with the advent of currency crisis 1999. 
Figure 3 illustrates the effects of operational fragility of two of the country's safety margins: the volume of international reserves and the performance of net exports. For Brazil, the results of their net exports depend mainly on exports of goods recorded in the trade balance. As the volume of reserves, the ability to generate autonomous currency in foreign currency through this account is considered an important factor for the formation of expectations of foreign investors. The effects of the fragility of these margins were estimated by the ratio between the stock of NFD and exports of goods and stocks of NFD and international reserves ${ }^{14}$ :

\section{Figure 3 NFD x Brazilian safety margins}

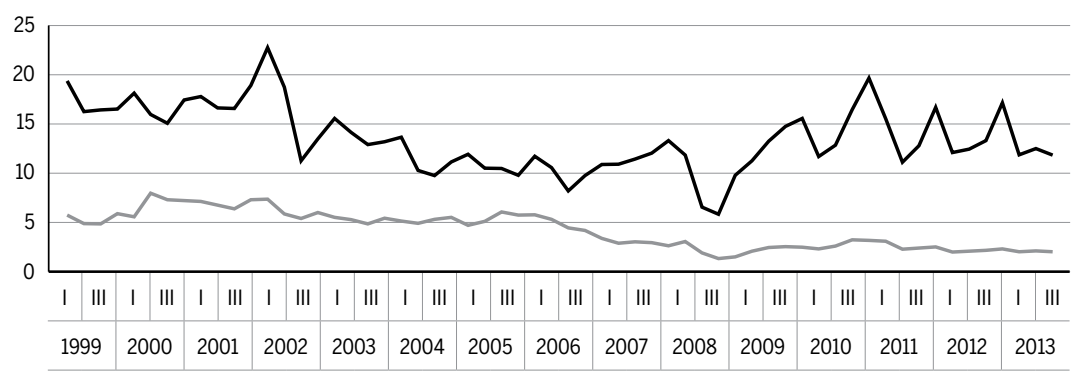

NFD/Exports of Goods NFD/Intern. Reserves (net, end of period)

Source: Banco Central do Brasil. Self-Elaboration.

The dimension of NFD is one of the factors responsible for determining the value of national income drained abroad at each period to serve external commitments. Thus, the ratio between NFD and GDP illustrates a third safety instrument of the external sector of the economy. Its growth should negatively affect the expectations of creditors on the returns on their investments and on the external solvency position of the country. Figure 4 illustrates this ratio, from the available annual data between 1999 and 2013, and its trend curve:

14 Between the last quarter of 2001 and 2013, NFD value was obtained by PII of Brazil data. Previous values are estimates, obtained, for each period $t$, through the difference between the stock of NFD in $t+1$ and balance of CA in $t+1$. The value of international reserves is given by the liquidity concept (end of period). 


\section{Figure 4 NFD x Brazilian safety margin}

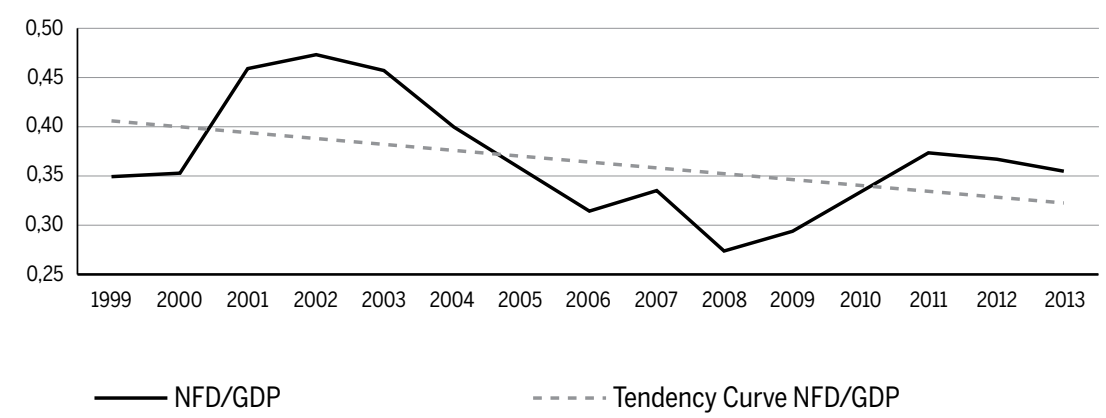

Source: Banco Central do Brasil and Instituto Brasileiro de Geografia e Estatística. Self-Elaboration.

Table 3 summarizes the results of Figures 3 and 4, using the average values of all the ratios for each of the three analyzed periods:

Table 3 BOP Information to external operational fragility measures

\begin{tabular}{lrrrr}
\hline Period & $\mathbf{1 9 9 9 - 2 0 0 2}$ & $\mathbf{2 0 0 3 - 2 0 0 7}$ & $\mathbf{2 0 0 8 - 2 0 1 3}$ \\
\hline NFD/Average Export. Goods & 16.950 & 11.441 & 12.920 \\
\hline NFD/Average Intern. Reserves & 6.353 & 4.783 & 2.351 \\
\hline NFD/Average GDP & 0.408 & 0.372 & 0.332 \\
\hline
\end{tabular}

Source: Banco Central do Brasil and Instituto Brasileiro de Geografia e Estatística. Self-Elaboration.

Values from Figures 3 and 4 and from Table 3 indicate that all safety margins had their worst results concerning NFD during the first period, became robust concerning NFD in the second period and maintained their path of relative improvement in the third period, the exception being only in the third period for exports of goods, that suffered a minor setback in their path of relative improvement, but presented a performance close to that of the previous period and thus much more satisfactory than the one observed in 1999-2002.

These results suggest that Brazil, since 2003, is gradually acquiring greater ability to sustain its external accounts. Although, in the third period, the external sector has submitted its worst operating results, characterizing the unsustainable Ponzi scheme, the accelerated growth of NFD was not enough to spoil their Safety Margins.

Finally, Figure 5 shows the relationship between current revenues, the total demand for foreign exchange and the participation of foreign financing in the balance of $\mathrm{BOP}$ accounts, the latter calculated in accordance 
with Table 4. The Figure also shows the trend curve of this last:

Table 4 BOP Information that compose Foreign Financing

\section{Foreign Financing}

Foreign direct investment credit;

Foreign portfolio direct investment credit;

Commercial Credit Inflow - LT Suppliers;

IMF Inflow;
Inflow of Other regularization operations

Inflow of Other LT Loans;

Inflow of Loans and Financing - other LT sectors.

Source: Banco Central do Brasil. Self-Elaboration.

Figure 5 Current revenue, total demand and foreign financing for BOP closure (US\$ Million)

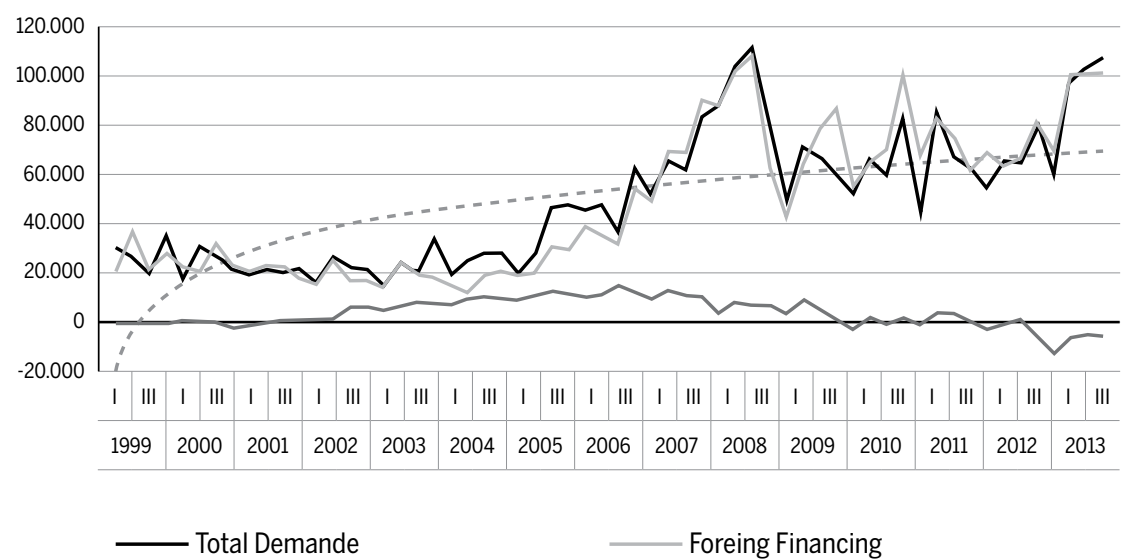

Source: Banco Central do Brasil. Self-Elaboration.

Across all years analyzed, there was a significant disparity between income and demand for current resources. For that reason, external financing has always had a majority stake in the role of ensuring the provision of foreign currency resources to the global closure of BOP. Since this participation is directly affected by the expansion of operational fragility, it realized, in the last period, its highest growth compared to the previous periods.

Results presented so far induce a question on the sustainability of $\mathrm{BOP}$ in the two periods in which the external sector was classified as Ponzi. The 1999 and 2001 crisis marked the only moments during the analyzed time frame in which the increased demand for foreign resources was not accompanied by a proportional supply of external financing. This mismatch 
between supply and demand has forced the country to use much of its foreign exchange reserves and to adopt a forced adjustment process of its external accounts to rebalance $\mathrm{BOP}$ and restore the confidence of foreign markets in the Brazilian economy. Therefore, the two currency crises leave no doubt about the inability of the country to ensure the balance of its external accounts during the period 1999-2002.

On the other hand, in the second Ponzi period, the rapid expansion of operational fragility led the country to an average demand for external resources 3 times higher than that of the first Ponzi period. However, unlike what happened in 1999 and in 2001, this time, the financial markets made an offer of foreign capital which, at various times, surpassed in large measure, the amount required for closing the $\mathrm{BOP}^{15}$. Thus, in this second Ponzi moment, the balance of the BOP was easily reached, showing that the progress of operational fragility was not enough to shake the confidence of international markets on the economy.

Explanations for the differences in the behavior of the external financial market in both Ponzi periods are developed throughout this section. For now, it was argued that the performance of the safety margins in relation to operational external fragility of the country was much higher in the second Ponzi period, which contributed to the more favorable expectations of creditors in the last period, ensuring better external financing conditions.

\subsection{Structural external fragility}

Table 5 presents the categories of capital from International Position of Brazilian Investment (PII) between December 2001 and December 2013 ${ }^{16}$ :

We start evaluating Gross Foreign debt (GED) from item OFI, where the bigger part of the foreign debt is. From 2001 to 2013, OFI increased 104\%, going from US\$97.1 billion to US\$198.2 billion. Despite the expansion path, OFI have been losing share in GED. In 2002, they represented $30.9 \%$ of GED, against $39.5 \%$ of FPI and $29.5 \%$ of FDI. In 2013 , their participation dropped considerably, reaching $13.2 \%$, against $38.2 \%$ of FPI and $48.2 \%$ of FDI.

15 The excess supply of foreign currency was so expressive that it enabled an extraordinary accumulation of foreign exchange reserves, the subject matter in the next subsection, reaching, in 2012, US\$379 billion, a historical record for Brazil.

16 Information available only from December 2001 on. 
Table 5 International position of Brazilian investment (PII) - US\$ Billion

\begin{tabular}{|c|c|c|c|c|c|c|c|c|c|c|c|c|c|}
\hline Discrimination & $\begin{array}{l}\text { Dec } \\
/ 01\end{array}$ & $\begin{array}{l}\text { Dec } \\
/ 02\end{array}$ & $\begin{array}{l}\text { Dec } \\
103\end{array}$ & $\begin{array}{l}\text { Dec } \\
/ 04\end{array}$ & $\begin{array}{l}\text { Dec } \\
/ 05\end{array}$ & $\begin{array}{l}\text { Dec } \\
106\end{array}$ & $\begin{array}{l}\text { Dec } \\
/ 07\end{array}$ & $\begin{array}{l}\text { Dec } \\
108\end{array}$ & $\begin{array}{l}\text { Dec } \\
109\end{array}$ & $\begin{array}{l}\text { Dec } \\
/ 10\end{array}$ & $\begin{array}{r}\text { Dec } \\
/ 11\end{array}$ & $\begin{array}{l}\text { Dec } \\
/ 12\end{array}$ & $\begin{array}{l}\text { Dec } \\
/ 13\end{array}$ \\
\hline $\begin{array}{l}\text { Foreign } \\
\text { Direct Inv. }\end{array}$ & 121.9 & 100.9 & 132.8 & 161.3 & 181.3 & 220.6 & 309.7 & 287.7 & 400.8 & 682.3 & 695.1 & 718.9 & 728.9 \\
\hline $\begin{array}{l}\text { Foreign } \\
\text { Portfolio Inv. }\end{array}$ & 151.5 & 135.1 & 165.8 & 184.6 & 232.2 & 304.2 & 508.4 & 287.5 & 562.6 & 668.5 & 600.8 & 638.8 & 577.6 \\
\hline Derivatives & 0.0 & 0.2 & 0.1 & 0.3 & 0.2 & 0.4 & 1.8 & 2.5 & 3.4 & 3.8 & 4.7 & 3.0 & 6.3 \\
\hline $\begin{array}{l}\text { Other } \\
\text { Foreign Inv. }\end{array}$ & 97.1 & 105.5 & 105.3 & 97.1 & 67.8 & 78.1 & 95.5 & 109.8 & 107.9 & 152.7 & 186.0 & 195.7 & 198.2 \\
\hline $\begin{array}{l}\text { Commercial } \\
\text { Credit }\end{array}$ & 6.2 & 9.1 & 8.7 & 4.5 & 4.7 & 4.8 & 10.7 & 16.6 & 2.1 & 2.0 & 1.9 & 1.9 & 1.7 \\
\hline Longterm & 5.2 & 6.7 & 8.2 & 4.3 & 4.5 & 4.7 & 10.6 & 16.1 & 1.9 & 1.9 & 1.8 & 1.9 & 1.7 \\
\hline Shortterm & 1.0 & 2.4 & 0.5 & 0.2 & 0.2 & 0.1 & 0.1 & 0.5 & 0.2 & 0.1 & 0.1 & 0.0 & 0.0 \\
\hline Loans & 84.2 & 87.4 & 91.4 & 83.6 & 55.6 & 66.8 & 76.7 & 84.7 & 100.6 & 145.8 & 179.0 & 188.5 & 191.3 \\
\hline Monetary Auth. & 9.2 & 21.5 & 28.9 & 25.4 & 0.3 & 0.2 & 0.0 & 0.0 & 0.0 & 0.0 & 0.0 & 0.0 & 0.0 \\
\hline Government & 22.1 & 22.4 & 20.7 & 19.4 & 18.0 & 18.2 & 18.2 & 19.2 & 20.5 & 24.0 & 20.0 & 25.5 & 28.2 \\
\hline Banks & 31.9 & 24.2 & 27.0 & 24.1 & 23.8 & 25.6 & 43.5 & 48.3 & 42.4 & 65.2 & 89.8 & 91.4 & 86.3 \\
\hline Longterm & 12.0 & 7.3 & 9.7 & 7.3 & 7.5 & 9.0 & 12.7 & 17.6 & 17.0 & 22.0 & 52.6 & 59.8 & 54.5 \\
\hline Shortterm & 19.9 & 17.0 & 17.3 & 16.9 & 16.3 & 16.6 & 30.9 & 30.8 & 25.4 & 43.2 & 37.1 & 31.6 & 31.8 \\
\hline Other Sector & 21.0 & 19.2 & 14.9 & 14.6 & 13.4 & 22.9 & 15.0 & 17.2 & 37.7 & 56.6 & 69.2 & 71.6 & 76.7 \\
\hline Longterm & 18.7 & 18.9 & 14.6 & 14.1 & 13.2 & 22.2 & 14.6 & 16.8 & 36.4 & 51.4 & 67.4 & 71.4 & 76.7 \\
\hline Shortterm & 2.3 & 0.3 & 0.3 & 0.5 & 0.2 & 0.6 & 0.4 & 0.5 & 1.4 & 5.2 & 1.8 & 0.2 & 0.0 \\
\hline $\begin{array}{l}\text { Currency / } \\
\text { deposits }\end{array}$ & 0.2 & 0.4 & 0.2 & 0.4 & 0.6 & 0.8 & 1.2 & 0.6 & 0.7 & 0.5 & 0.6 & 0.9 & 0.9 \\
\hline Other Debts & 6.6 & 8.7 & 4.9 & 8.6 & 6.9 & 5.8 & 6.9 & 7.9 & 4.5 & 4.4 & 4.4 & 4.4 & 4.4 \\
\hline Foreign debts & 370.6 & 341.8 & 404.0 & 443.3 & 481.5 & 603.4 & 915.4 & 687.5 & 1074.7 & 1507.3 & 1486.6 & 1556.4 & 1511.1 \\
\hline $\begin{array}{l}\text { Brazilian } \\
\text { Direct Invest. }\end{array}$ & 49.7 & 54.4 & 54.9 & 69.2 & 79.3 & 113.9 & 141.9 & 157.8 & 167.1 & 191.3 & 206.2 & 270.9 & 293.3 \\
\hline $\begin{array}{l}\text { Brazilian } \\
\text { Portfolio Invest. }\end{array}$ & 6.4 & 5.8 & 7.0 & 9.4 & 10.8 & 14.4 & 19.3 & 14.6 & 16.5 & 38.2 & 28.5 & 22.1 & 26.6 \\
\hline Derivatives & 0.0 & 0.1 & 0.1 & 0.1 & 0.1 & 0.1 & 0.1 & 0.6 & 0.4 & 0.8 & 0.7 & 0.6 & 0.6 \\
\hline $\begin{array}{l}\text { Other } \\
\text { Brazilian invest. }\end{array}$ & 16.9 & 16.4 & 25.3 & 20.1 & 28.0 & 29.1 & 42.9 & 45.4 & 44.1 & 51.6 & 54.8 & 64.0 & 67.8 \\
\hline Reserve Assets & 35.9 & 37.8 & 49.3 & 52.9 & 53.8 & 85.8 & 180.3 & 193.8 & 238.5 & 288.6 & 352.0 & 373.1 & 358.8 \\
\hline Foreign Assets & 108.9 & 114.6 & 136.5 & 151.7 & 172.0 & 243.4 & 384.5 & 412.2 & 466.7 & 570.5 & 642.1 & 730.7 & 747.0 \\
\hline Net Foreign debt & 261.7 & 227.2 & 267.5 & 291.6 & 309.5 & 360.0 & 530.8 & 275.3 & 608.0 & 936.8 & 844.5 & 825.6 & 764.0 \\
\hline
\end{tabular}

Source: Banco Central do Brasil. Self-Elaboration. 
A second feature of the composition of OFI that stuck throughout all analyzed time frames was the majority of Long Term (LT). Short Term (ST) OFI never represented more than $6.3 \%$ of GED, lying, must of the time, below 4\% and, in 2012 and 2013, in $2.1 \%$ and $2.2 \%$, respectively. On an annual average, from 2001 to 2013, LTOFI ${ }^{17}$ represented 13\% of GED, while STOFI represented only $3.7 \%$ of GED.

Information OFI participation in GED can be found in Table 6, which illustrates the percentage composition of the main items of debts and foreign assets in Brazil:

Table 6 Percentage composition of the international investment position of Brazil

\begin{tabular}{|c|c|c|c|c|c|c|c|c|c|c|c|c|c|}
\hline Discrimination & $\begin{array}{c}\text { Dec } \\
/ 01\end{array}$ & $\begin{array}{l}\text { Dec } \\
/ 02\end{array}$ & $\begin{array}{l}\text { Dec } \\
/ 03\end{array}$ & $\begin{array}{l}\text { Dec } \\
/ 04\end{array}$ & $\begin{array}{l}\text { Dec } \\
/ 05\end{array}$ & $\begin{array}{l}\text { Dec } \\
\text { /06 }\end{array}$ & $\begin{array}{l}\text { Dec } \\
/ 07\end{array}$ & $\begin{array}{l}\text { Dec } \\
108\end{array}$ & $\begin{array}{l}\text { Dec } \\
109\end{array}$ & $\begin{array}{l}\text { Dec } \\
/ 10\end{array}$ & $\begin{array}{r}\text { Dec } \\
/ 11\end{array}$ & $\begin{array}{l}\text { Dec } \\
/ 12\end{array}$ & $\begin{array}{l}\text { Dec } \\
/ 13\end{array}$ \\
\hline $\begin{array}{l}\text { Foreign } \\
\text { Direct Inv. }\end{array}$ & 32.9 & 29.5 & 32.9 & 36.4 & 37.7 & 36.6 & 33.8 & 41.8 & 37.3 & 45.3 & 46.8 & 46.2 & 48.2 \\
\hline $\begin{array}{l}\text { Foreign } \\
\text { Portfolio Inv. }\end{array}$ & 40.9 & 39.5 & 41.0 & 41.6 & 48.2 & 50.4 & 55.5 & 41.8 & 52.3 & 44.3 & 40.4 & 41.0 & 38.2 \\
\hline Derivatives & 0.0 & 0.1 & 0.0 & 0.1 & 0.0 & 0.1 & 0.2 & 0.4 & 0.3 & 0.3 & 0.3 & 0.2 & 0.4 \\
\hline $\begin{array}{l}\text { Other } \\
\text { Foreign LTInv. }\end{array}$ & 19.9 & 25.0 & 21.5 & 17.9 & 10.5 & 9.9 & 6.9 & 11.3 & 7.5 & 6.9 & 9.8 & 10.5 & 11.0 \\
\hline $\begin{array}{l}\text { Other } \\
\text { Foreign STInv. }\end{array}$ & 6.3 & 5.9 & 4.6 & 4.1 & 3.6 & 3.0 & 3.6 & 4.7 & 2.6 & 3.2 & 2.7 & 2.1 & 2.2 \\
\hline Foreign debt & 100.0 & 100.0 & 100.0 & 100.0 & 100.0 & 100.0 & 100.0 & 100.0 & 100.0 & 100.0 & 100.0 & 100.0 & 100.0 \\
\hline Invest. Abroad & 67.1 & 67.0 & 63.9 & 65.1 & 68.7 & 64.7 & 53.1 & 53.0 & 48.9 & 49.4 & 45.2 & 48.9 & 52.0 \\
\hline Reserve Assets & 32.9 & 33.0 & 36.1 & 34.9 & 31.3 & 35.3 & 46.9 & 47.0 & 51.1 & 50.6 & 54.8 & 51.1 & 48.0 \\
\hline Foreign Assets & 100.0 & 100.0 & 100.0 & 100.0 & 100.0 & 100.0 & 100.0 & 100.0 & 100.0 & 100.0 & 100.0 & 100.0 & 100.0 \\
\hline LTGED/GED & 52.8 & 54.5 & 54.4 & 54.2 & 48.1 & 46.5 & 40.7 & 53.1 & 44.8 & 52.2 & 56.6 & 56.7 & 59.2 \\
\hline STGED/GED & 47.2 & 45.5 & 45.6 & 45.8 & 51.9 & 53.5 & 59.3 & 46.9 & 55.2 & 47.8 & 43.4 & 43.3 & 40.8 \\
\hline STGE/Res. Ass. & 4.88 & 4.11 & 3.74 & 3.83 & 4.64 & 3.76 & 3.01 & 1.66 & 2.49 & 2.50 & 1.83 & 1.81 & 1.72 \\
\hline ST GE/GDP & 0.32 & 0.31 & 0.33 & 0.31 & 0.28 & 0.30 & 0.40 & 0.20 & 0.37 & 0.34 & 0.26 & 0.30 & 0.27 \\
\hline
\end{tabular}

Source: Banco Central do Brasil. Self-Elaboration.

The most representative accounts of GED during the analyzed time frame were FPI and FDI. In the first two phases, their stocks followed their growth

17 Item LTOFI includes the sub-accounts: long-term commercial credit; loans to the monetary authority, government loans, loans to long-term banks; loans to other long-term sector and other liabilities. Item STOFI includes the sub-accounts: short term commercial credit; loans to short-term banks; loans to other short-term sector and currency and deposits. 
trajectories. However, the first item expanded, in general, at greater speed when compared to the second. Therefore, in every year between 2001 and 2007, the FPI values exceeded those of FDI and the difference between them increased year by year. On the other hand, from 2008 to 2013, there was a change in the behavior of these series. While the FDI followed a general trend of growth, the FPI alternated years of growth and downturn. As a result, in this third phase, the stock of FDI not only surpassed that of FPI, with one exception in 2009, but also grew at higher rates. Table 7 can evidence this change in the behavioral pattern of the stocks:

Table 7 FPI and FDI stock differences

\begin{tabular}{|c|c|c|c|c|c|c|c|c|c|c|c|c|c|}
\hline Discrimination & $\begin{array}{c}\text { Dec } \\
/ 01\end{array}$ & $\begin{array}{l}\text { Dec } \\
/ 02\end{array}$ & $\begin{array}{l}\text { Dec } \\
/ 03\end{array}$ & $\begin{array}{l}\text { Dec } \\
/ 04\end{array}$ & $\begin{array}{l}\text { Dec } \\
/ 05\end{array}$ & $\begin{array}{l}\text { Dec } \\
/ 06\end{array}$ & $\begin{array}{l}\text { Dec } \\
/ 07\end{array}$ & $\begin{array}{l}\text { Dec } \\
108\end{array}$ & $\begin{array}{c}\text { Dec } \\
/ 09\end{array}$ & $\begin{array}{l}\text { Dec } \\
/ 10\end{array}$ & $\begin{array}{r}\text { Dec } \\
/ 11\end{array}$ & $\begin{array}{c}\text { Dec } \\
/ 12\end{array}$ & $\begin{array}{l}\text { Dec } \\
/ 13\end{array}$ \\
\hline FPI-FDI & 29.5 & 34.3 & 33.0 & 23.3 & 50.8 & 83.6 & 198.7 & -0.2 & 161.8 & -13.9 & -94.3 & -80.1 & -151.4 \\
\hline
\end{tabular}

Source: Banco Central do Brasil. Self-Elaboration.

At the end of Table 6, the accounts that compose the Brazilian foreign debt were grouped, according to their bias of short term (ST GED) or long term (LTGED), and presented according its participation in GED ${ }^{18}$. The evolution of these series is in Figure 6, quarterly valued. The green bars show periods and dimensions in which LTGED/GED exceeded ST GED/GED, while red bars show the opposite:

Figure 6 Brazilian external debt composition

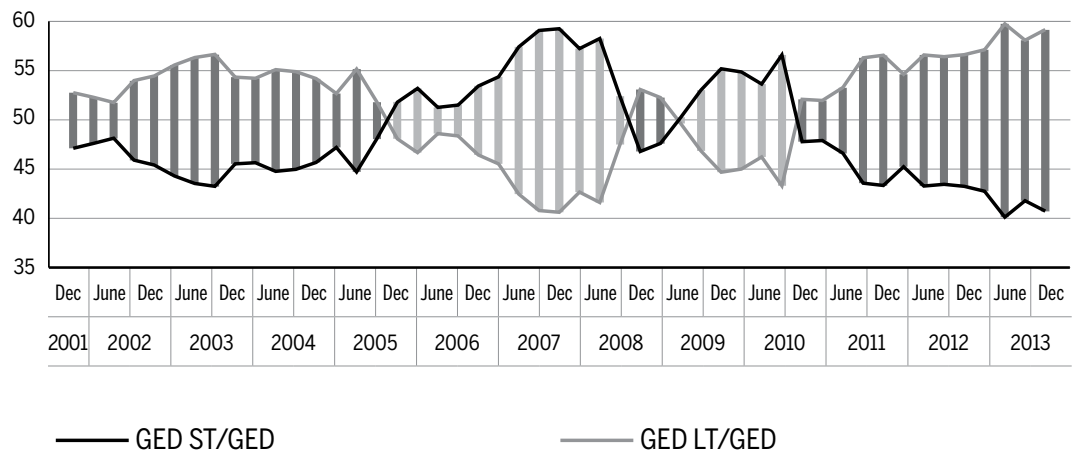

Source: Banco Central do Brasil. Self-Elaboration.

18 STGED accounts are: FPI, derivatives and STOFI. LTGED accounts are: FDI and LTOFI. 
Generally, short-term capital participation in GED was higher during the period characterized as euphoria of international markets and strong recovery of Brazilian macroeconomics indexes. On the other side, this participation falls during the period when there is a greater mistrust of those markets on the country, in 2001 and 2002, as well as during the post-crisis scenario of 2008, that was characterized by domestic measures of speculative capital control and by the increasing influx of FDI in the country ${ }^{19}$.

With Brazilian GED already described, now presented is the foreign assets item ${ }^{20}$ that is relevant for the measuring of the external structural fragility, reserve assets.

Between 2001 and 2005, reserve assets had a small ascendant trajectory, going from US\$35.9 billion to US $\$ 53.8$ billion, a movement strongly accelerated from 2006 on, with the beginning of the aggressive policy of reserve composition. These interventions, motivated by the necessity of diminishing excessive currency volatility and reducing the country's external fragility, resulted in as even-fold increase of the reserves, if compared to 2005 , reaching the mark of US $\$ 358.8$ billion in 2013 . Therefore, this item gained, gradually, greater participation in the country's foreign assets, going from $32.9 \%$ in 2001 to $54.8 \%$ in 2011 and $48 \%$ in 2013, as shown in Figure 7. The green bars show periods and the dimension in which the reserves have exceeded other investments in the composition of foreign assets, while red illustrate the opposite.

From equation (7), described in the subsection 2.2.2, Figure 8 shows the evolution of Brazilian structural external fragility, quarterly valued, between 2001 and 2013, and its trend curve.

A first observation of the ratio STGED/Reserve Assets is that, along all time frames, forms of debt with short-term bias exceeded the assets of immediate liquidity. This means that in the event of a severe currency crisis, with the entire liabilities of greater volatility escaping to the exterior, the country would be "uncovered." Thus, in relation to structural external fragility, it is clear that the country has always been in speculative or Ponzi position.

19 The performance of FDI in the last period served as a major damper to the economy against the contagion effect produced by financial instability in developed countries due to the euro crisis deepening, counterbalancing the unstable trajectory of speculative capital. (Prates; Cunha, 2013).

20 External asset consists of the items: Brazilian direct investment abroad, portfolio investments, other investments, derivatives and reserve assets. In Table 6, the item "investments abroad" is the sum of the first four items, i.e., external assets minus reserve assets. 
Figure 7 Brazilian foreign assets composition

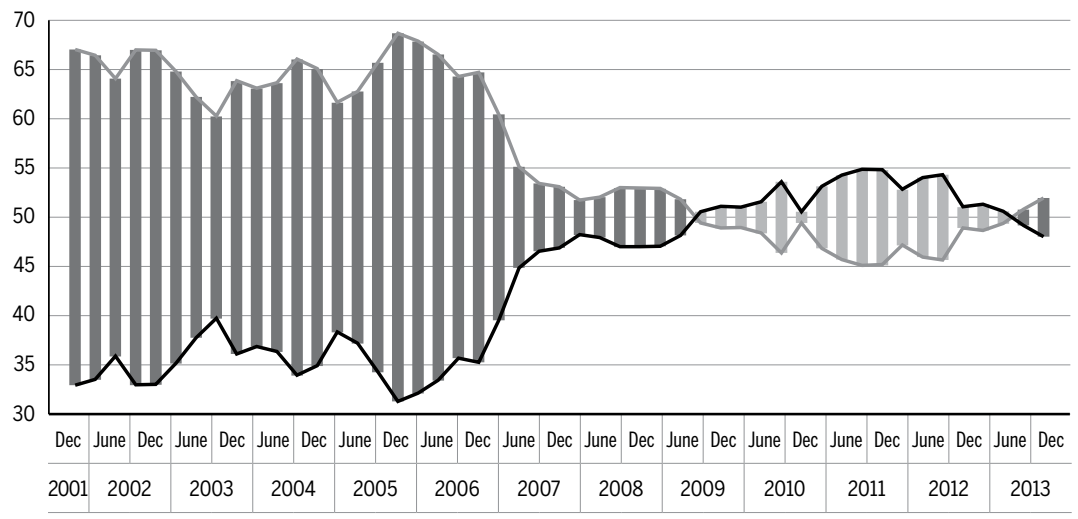

_ Reserve Assets/Foreign Assets Gross __ Foreign Invest/Foreign Assets Gross

Source: Banco Central do Brasil. Self-Elaboration.

Figure 8 Structural external fragility of Brazil

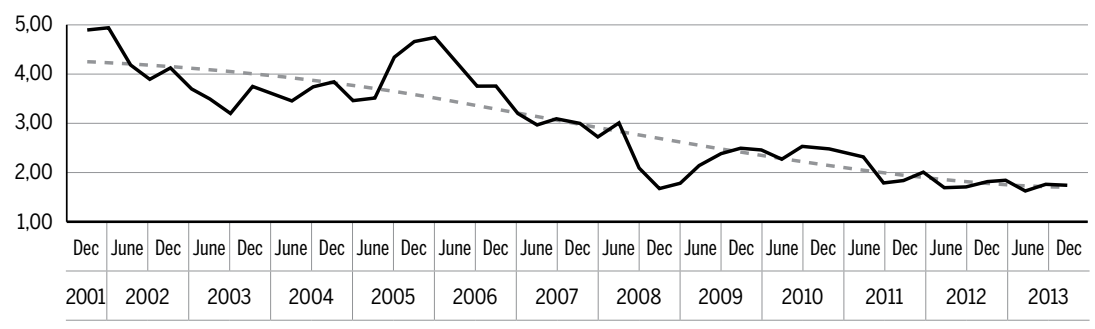

— GED ST/Reserve Assets

- - - - . Tendency curve GED ST/Reserve Assets

Source: Banco Central do Brasil. Self-Elaboration.

On the other hand, a comparative assessment shows that the structural fragility showed, in general, a sharp downward trend from $66 \%$ during the years analyzed. Between 2001 and 2013, although the STGED has grown 3.5 times, foreign exchange reserves increased 10 times. As a result, the ratio plummets from a value of almost 5 in 2001 and 2002 to 1.62 in 2013.

Therefore, despite the insufficiency of the movement to disfigure the speculative or Ponzi position adopted by the Brazilian external sector, the fact is that the latter is structurally less vulnerable in these recent years than it was thirteen years ago. 


\subsection{External fragility: joint assessment of the operational and structural fragilities and its consequences on the Brazilian exter- nal sector}

The first index analyzed here is the one proposed in equation (3), which was developed in subsection 2.2. This equation is built for the Brazilian economy, according to Table 8:

Table 8 BOP information that compose EFFI

\begin{tabular}{|c|c|}
\hline \multicolumn{2}{|r|}{ Open Financial Positions } \\
\hline \multicolumn{2}{|r|}{ Real } \\
\hline M: imports & Imports of goods \\
\hline $\mathrm{D}_{\mathrm{j}}$ : interest expenses & Income Expenses \\
\hline$D_{\text {os }}$ : other services expenses & $\begin{array}{l}\text { Services Expenses; } \\
\text { Current Unilateral Transfers Expenses; } \\
\text { Unilateral Transfer of Capital Expenses }\end{array}$ \\
\hline A: amortizations & $\begin{array}{l}\text { Amortization of commercial credit - LT suppliers; } \\
\text { Amortization IMF; } \\
\text { Amortization of others regularization operations; } \\
\text { Amortization of others LT loans; } \\
\text { Amortization of loans and financing-other LT sectors; } \\
\text { Foreign direct investment debt }\end{array}$ \\
\hline \multicolumn{2}{|r|}{ Virtual } \\
\hline CST: short-term capitals ${ }^{1}$ & $\begin{array}{l}\text { Stock of derivatives; } \\
\text { Stock of other foreign investments - short-term trade credit; } \\
\text { Stock of other foreign investments - short term loans to banks; } \\
\text { Stock of other foreign investments - loans to other short-term } \\
\text { sectors; } \\
\text { Stock of other foreign investment - Currency and deposits }\end{array}$ \\
\hline PLA: liquid investment in portfolio 2 & Stock of foreign portfolio investments \\
\hline
\end{tabular}

Available Resources

\begin{tabular}{l|l}
\hline \multicolumn{2}{c}{ Current Revenue and International Reserves } \\
\hline $\mathrm{X}:$ exports & Exports of goods \\
\hline $\mathrm{R}_{\mathrm{j}}$ interest revenue & Income Expenses \\
\hline $\mathrm{R}_{\mathrm{os}}$ : other services revenue & $\begin{array}{l}\text { Services Expenses; } \\
\text { Current Unilateral Transfers Expenses; } \\
\text { Unilateral Transfer of Capital Expenses }\end{array}$ \\
\hline RE: international reserves & Stock of International Reserves - liquidity concept \\
\hline
\end{tabular}




\begin{tabular}{l|l}
\hline \multicolumn{2}{c}{ Loans and Financing of Medium and Long Term } \\
\hline $\begin{array}{l}\mathrm{I}_{\mathrm{d}} \text { : foreign currency } \\
\text { Direct investments }\end{array}$ & Credit of foreign direct investment \\
\hline $\mathrm{E}_{\mathrm{ml}}$ : medium andlongterm loans & $\begin{array}{l}\text { Inflow of commercial credit - LT suppliers; } \\
\text { Inflow IMF; } \\
\text { Inflow of other regularization operations; } \\
\text { Inflow of other LT loans; } \\
\text { Inflow of loans and financing - other LT sectors }\end{array}$ \\
\hline
\end{tabular}

Source: Banco Central do Brasil. Self-Elaboration.

1 Values from December 2001 on were extracted from the International Position of Brazilian Investment (PIl do Brasil). Previous values come from the series "Gross Short-Time External Debt", made available by BCB. 2 Values from December 2011 on were extracted from Pll of Brazil. Previous data were calculated from the sum, since 1990, of FPI flows (net) of the BOP.

Figure 9 shows the quarterly evolution of the EFFI between 1999 and 2013 and its trend curve:

Figure 9 External financial fragility index

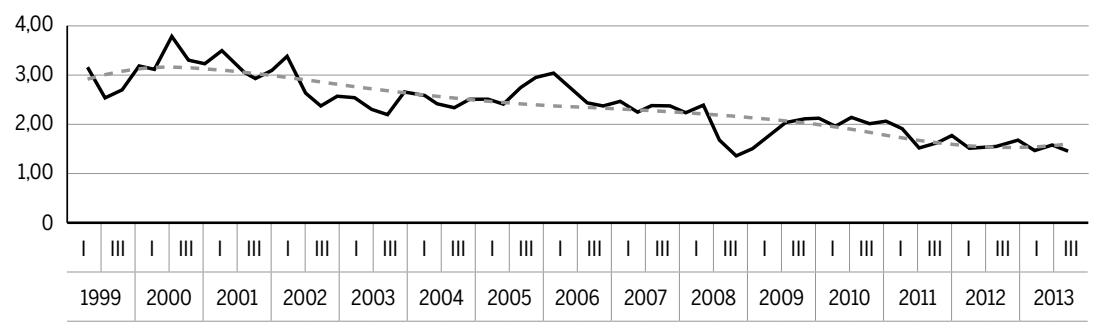

- External Financial Fragility Index - - - - - Tendency curve EFFI

Source: Banco Central do Brasil. Self-Elaboration.

According to Figure 9, EFFI was always over 1 (one), which indicates that real and virtual obligations in foreign currency exceeded the country's payment capacity throughout the entire evaluated time frame. Therefore, Brazil has always depended on refinancing in the external markets to fulfil a part of its most immediate financial commitments with non-residents, assuming, hence, a speculative or Ponzi position.

On the other hand, it appears that the external fragility followed, generally, a downward path of 61\% between 1999 and 2013, ranging from a ratio that went from 3.79 , in 2000 , to 1.47 . Thus, the real and virtual 
external obligations of the economy were increasingly being covered by a combination of current income, LT external financing sources and foreign exchange reserves.

According to the EFFI, the Brazilian foreign sector was more vulnerable to destabilizing factors, precisely during the period comprising the two currency crises suffered by the country between 1999 and 2002. At this stage, the high operational imbalances amounted to the worst composition of the external financial structure observed throughout the time frame.

In the next phase, between 2003 and 2007, the external fragility has decreased, being at an intermediate level in respect to the other two periods. This was due to the significant recovery of CA surpluses associated with the fall of the ratio between the stocks of short-term liabilities and assets with immediate liquidity.

Finally, between 2008-2013, the financial structure of the Brazilian external sector was in its least fragile condition of the entire series. While under the operational perspective the fragility has submitted its worst results of all the time frame, under the structural perspective the fragility was the lowest among all the periods, with structural results more than enough to offset the operating deficits.

Assessing the EFFI trend curve, it is evident that its overall downward trend slows in 2012 and stabilizes in 2013, suggesting that it should remain more or less stable, that is, with values hovering around 1.5, over the coming years in the short term.

Thus, if the fragility of the external sector followed a downward path, then the balance of the BOP was reached gradually with greater ease. The most robust external financial structure resulted in increased credibility of the economy with international markets, better return expectations of applied investments and greater optimism about its ability to remain solvent. Therefore, there was an increase in supply of external financing available to the country, which facilitated the closure of $\mathrm{BOP}$ accounts. As a result of better financing conditions, BOP instabilities became gradually less likely and frequent, as well as their real and financial consequences being lower.

The second index built in this subsection seeks to evaluate the interpretation developed in the previous paragraph. Its calculation is made from equation (4), developed in subsection 2.2. BOP accounts in Brazil that compose the current EFFI are listed in Table 9: 
Table 9 BOP information that compose current EFFI

\begin{tabular}{l|l}
\hline Current demand for foreign currency (DECME) & Current availability of foreign currency (DICME) \\
\hline Imports of goods & Exports of goods \\
\hline Services expenses & Services revenues \\
\hline Income expenses & Income revenues \\
\hline Current unilateral transfers expenses & Current unilateral transfers revenues \\
\hline Unilateral capital transfers expenses & Unilateral capital transfers revenues \\
\hline Debt with Brazilian direct investment & Credit with Brazilian direct investment \\
\hline Debt with foreign direct investment & Credit with foreign direct investment \\
\hline Brazilian portfolio investment application & Brazilian portfolio investment return \\
\hline Debt with foreign portfolio investment & Credit with foreign portfolio investment \\
\hline Derivatives - liabilities (net) & Derivatives - assets (net) \\
\hline Disbursement with LT loans and financing & Amortization received from LT loans and financing \\
\hline Other LT and ST liabilities (net) & Other LT and ST assets (net) \\
\hline Commercial credit - LT Suppliers - Amortization & Commercial credit - LT Suppliers - Inflow \\
\hline IMF - Amortization & IMF - Inflow \\
\hline Other regularization operations - Amortization & Other regularization operations - Inflow \\
\hline Other LT loans - Amortization & Other LT loans- Inflow \\
\hline Loans and financing - other LT sectors - & Loans and financing - other LT sectors - Inflow \\
\hline Amortization & \\
\hline So &
\end{tabular}

Source: Banco Central do Brasil. Self-Elaboration.

Figure 10 shows results of current EFFI applied to Brazilian economy:

Figure 10 Current external financial fragility index

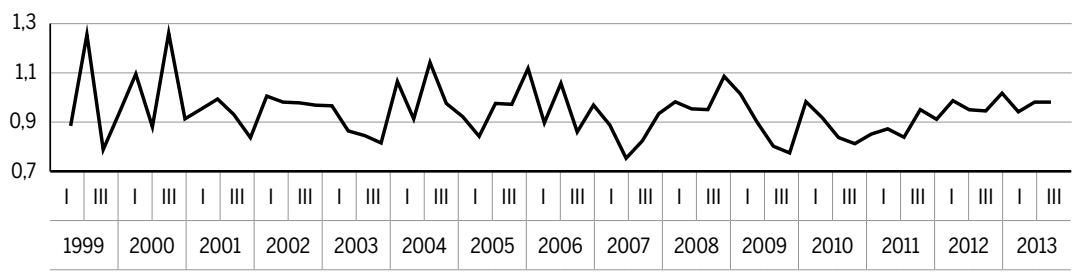

Current EFFI

Source: Banco Central do Brasil. Self-Elaboration.

The results of the oscillation amplitudes indicate that the BOP flows have had, over the years, less and less frequent levels of instability, while the 
average values of the current EFFI show that the average availability of foreign capital was gradually higher than demand. Both findings are highlighted in Table 10, by calculating the standard deviation and the average current EFFI for each period:

Table 10 Current EFFI - Standard deviation and average values

\begin{tabular}{lrrrr}
\hline Period & 1999-2002 & 2003-2007 & 2008-2013 \\
\hline Standard Deviation & 0.128 & 0.104 & 0.077 \\
\hline Current Average EFFI & 0.984 & 0.931 & 0.926 \\
\hline
\end{tabular}

Source: Banco Central do Brasil. Self-Elaboration.

The reduction of extreme values of Figure 10 over the three phases is another parameter for evaluating that domestic and/or international shocks have produced, with the passage of time, capital leakage to the exterior, that were diminishing in intensity, possibly triggering less damage effects to the economy. Table 11 compares the highest peaks of current EFFI in each period and points to their main generator event:

Table 11 Current EFFI - Extreme values per period

\begin{tabular}{lrr|r}
\hline Period & $\mathbf{1 9 9 9 - 2 0 0 2}$ & $\mathbf{2 0 0 3 - 2 0 0 7}$ & $\mathbf{2 0 0 8 - 2 0 1 2}$ \\
\hline Triggering Factor & $\begin{array}{r}\text { 1999 Brazilian and } \\
\text { 2000 Argentine Crises }\end{array}$ & $\begin{array}{r}\text { Pay Foreign debt } \\
\text { IMF 2004 }\end{array}$ & $\begin{array}{r}\text { International Financial } \\
\text { Crisis 2008 }\end{array}$ \\
\hline Current EFFI & 1.254 and1.259 & 1.141 & 1.085 \\
\hline
\end{tabular}

Source: Banco Central do Brasil. Self-Elaboration.

Therefore, current EFFI results converge with the conclusions developed from the first EFFI on the gradual reduction of Brazilian external fragility between 1999 and 2013.

\section{Concluding remarks}

In this work, we sought to accomplish two goals. The first was to develop an interpretation to open economies of the financial fragility hypothesis of Minsky on the generating process of currency crises and its determinants. From that, indexes were devised to evaluate the propensity of an economy to suffer a currency crisis. 
We argued that currency crises are products of changes in international financing conditions responsible for the mismatch between supply and demand of foreign currency in the BOP of a country. Admitting money supply as endogenously determined in foreign markets, its variation depends on the expectations of foreign investors about the profit opportunities offered by the economy and the solvency condition of its external sector, both conditioned by their external financial structure. Thus, its operational and structural deterioration, which are necessarily evaluated jointly, is the factor responsible for raising the level of external fragility of a country and thus its propensity to crises.

Our contribution to the literature on currency crisis sought to demonstrate the importance of a comprehensive analysis in the investigation of external fragility on countries. We sought to highlight the insufficient character of those studies that focus exclusively on the operating results of the BOP, particularly on the CA balances, or only on the composition of foreign debt, understood in isolation. For this work, the resilience of the external sector to disruptive events depends on the combination of both factors and their relationship to the foreign assets and the country's safety margins.

This interpretation associated with the set of indicators developed was used to fulfill the second goal proposed by this research, which sought to evaluate the evolution of external fragility of the Brazilian economy between 1999 and 2013.

Overall, the results suggest that the Brazilian external fragility followed a downward path, falling by half over the estimated time frame. The key element to support this view was the performance of foreign exchange reserves, which, between 1999 and 2013, grew much more rapidly than the operating deficits of the BOP and short-term and high volatility external liabilities. A second contributing factor was the significant inflow of FDI in the country, especially from 2006 , reducing the need to attract speculative capital to ensure the closure of its external accounts. Additionally, one should take into account the set of regulatory measures implemented by the government after the international crisis of 2008 to discourage the inflow of FPI.

Finally, the analysis of the trend curve of external fragility in recent years suggests the end of his long downward trend and the beginning of a stable trajectory, at least for the next few years in the short term. 
Theoretical and empirical results of this research are considered satisfactory, because they were able to explain the behavior of the Brazilian external sector in a convergent way to the main events that have affected it between 1999 and 2013, in particular the currency crisis of 1999 and 2001 and the unprecedented resistance capacity of the country to the international financial crisis of 2008. In addition, the interpretation developed here and applied to the Brazilian economy is in line with the traditional indicators of foreign debt and the ratings and perspectives of foreign markets for the country, expressed by the risk-Brazil and the rating set by international credit agencies, all signaling a trend of reduction in external vulnerability.

Despite the convergence with traditional external indicators, considered insufficient by studies of critical aspects, our analysis method is not restricted to cyclical or short-term aspects of the country and its external sector. Instead, it has considered the structural and long-term features of an economy, which, according to the defenders of their importance to the analysis of external fragility, manifest themselves on national foreign accounts by the tendency to imbalances in CA and the deterioration of composition of its foreign debts and assets.

In this sense, if the deficiencies on the Brazilian economic structure produce a tendency to flow and stock imbalances of its BOP, as argued by those authors dedicated to the structural issue, then the results of this research sought to show that between 1999 and 2013, this trend was not expressed in sufficient intensity to destroy the safety margins of the country's external sector and increase its external fragility.

\section{References}

ARESTIS, P.; GLICKMAN, M. Financial crisis in Southeast Asia: dispelling illusion the minskyan way. Cambridge Journal of Economics, London, v. 26, n. 2, p. 237-260, 2002.

ARESTIS, P.; PAULA, L. F. Financial liberalization and economic performance in emerging countries. Basingstoke: Palgrave Macmillan, 2008. 221 p.

ARESTIS, P.; SAWYER, M. (Ed.). A biographical dictionary of dissenting economists. $2^{\text {nd }}$ Ed. Cheltenham and Northampton: Edward Elgar Publishing, 2000. 722 p.

BANCO CENTRAL DO BRASIL. Contas externas. Brasília: PMF 8, 2013a. (Série perguntas mais frequentes). Available in: <http://www4.bcb.gov.br/pec/gci/port/focus/faq.asp>. Accessed August 28, 2014. 
BANCO CENTRAL DO BRASIL. Mudanças recentes no passivo externo brasileiro: relatório de inflação. Brasília, 2008. p. 107-111. Available at:<http://www.bcb.gov.br/htms/relinf/ port/2008/12/ri200812b5p.pdf $>$. Accessed August 24, 2014.

BANCO CENTRAL DO BRASIL. Risco-país. Brasília, 2013b. (Série Perguntas mais Frequentes). Available at:<http://www4.bcb.gov.br/pec/gci/port/focus/faq.asp >. Accessed August 28, 2014

BARROS, L. C. M. Folha de São Paulo, 8 Feb. 2008a.

BARROS, L. C. M. Um novo futuro. Novos Estudos CEBRAP, São Paulo, n. 81, p. 11-20, 2008 b.

BAUMANN, R.; CANUTO, O.; GONÇALVES, R. Economia internacional: teoria e experiência brasileira. 4. ed. Rio de Janeiro: Campus, 2004. 442 p.

CARCANHOLO, M. Inserção externa e vulnerabilidade da economia brasileira no governo Lula. In: CORECON-RJ. Os anos Lula. Contribuições para um balanço crítico 2003-2010. Rio de Janeiro: Garamond, 2010. p. 109-132.

CARNEIRO, R. O desenvolvimento brasileiro pós-crise financeira: oportunidades e riscos. Observatório da Economia Global, Campinas, n. 4, 2010. Available at:<http://www.centrocelsofurtado.org.br/adm/enviadas/doc/pt_00000122_20100825134137.pdf>. AccessedJune 5, 2014.

CORREA, V. P.; MOLLO, M. R. L.; BIAGE; M. Vulnerabilidade de mercado x vulnerabilidade de país: a volatilidade dos fluxos financeiros no Brasil e a continuidade da instabilidade. In: ENCONTRO NACIONAL DE ECONOMIA, 36., 2008, Salvador. Anais... Salvador: Associação Nacional de Pós-Graduação em Economia, 2008. Available at:<http://www. anpec.org.br/encontro2008/artigos/200807211150260-.pdf>. Accessed August 25, 2014.

CORREA, V. P.; MUNHOZ, V. C. V.; PEREIRA, V. P. A volatilidade da conta financeira do balanço de pagamentos de países selecionados da América Latina e da Ásia no período 1990-2010. In: ENCONTRO INTERNACIONAL DA ASSOCIAÇÃO KEYNESIANA BRASILEIRA, 5., 2012, São Paulo. Anais... São Paulo: Associação Keynesiana Brasileira, 2012. Available at:<http://www.akb.org.br/upload/140820121141117870_Vanessa\%20 Petrelli\%20Corr\%C3\%AAa.pdf>. Accessed August 27, 2014.

COUTINHO, L. A construção de fundamentos para o crescimento sustentável da economia brasileira. In: ALÉM, A. C.; GIAMBIAGI, F. (Org.). O BNDES em um Brasil em transição. Rio de Janeiro: BNDES, 2010. p. 17-36.

DYMSKI, G. A. Economia de bolha e crise financeira no Leste Asiático e na Califórnia: uma perspectiva espacializada de Minsky. Economia e Sociedade, Campinas, n. 11, p. 73-136, 1998.

FRANCO, G. H. B. Inserção externa e desenvolvimento: o consenso envergonhado. Revista Interesse Nacional, São Paulo, v. 1, n. 1, 2008. Available at: <http://interessenacional.uol. com.br/index.php/edicoes-revista/insercao-externa-e-desenvolvimento-o-consenso-envergonhado/>. Accessed August 25, 2014.

GENTIL, D. L.; ARAÚJO, V. L. Dívida pública e passivo externo: onde está a ameaça? Instituto de Pesquisas Econômicas Aplicadas, p. 1-21, 2012.

GONÇALVES, R. Ciclo econômico global e vulnerabilidade externa estrutural do Brasil. Online, 2012. Available at: <http://www.ie.ufrj.br/hpp/intranet/pdfs/ciclo_economico_e_ vulnerabilidade_rg_30_08_2012.pdf>. Accessed June 5, 2014. 
GRAY, H. P.; GRAY, J. M. Minskian fragility in the international financial system. In: DYMISKY, G.; POLLIN, R. (Ed.). New perspectives in monetary macroeconomics: explorations in the tradition of Hyman P. Minsky. Michigan: Michigan Press, 1994. p. 143-168.

GRIFFITH-JONES, S.; OCAMPO, J. A.; STIGLITZ, J. E. Time for a visible hand: lessons from the 2008 world financial crisis. New York: Oxford University Press, 2010. 384 p.

KALTENBRUNNER, A.; PAINCEIRA, J. P. New forms of external vulnerability: Brazil in the global financial crisis. In: CONFERENCE OF THE DEVELOPMENT STUDIES ASSOCIATION, CURRENT CRISIS AND NEW OPPORTUNITIES, 2009, Ulster. Proceedings... UIster: Development Studies Association, University of Ulster, 2009. Available at: <http:// www.devstud.org.uk/aqadmin/media/uploads/4af1730c98ea5_Painceira-kaltenbrunnerconf09.pdf $>$. Accessed August 28, 2014.

KEYNES, J. M. The general theory of employment, interest and money. New York: Harcourt Brace Jovanovich, 1964. $366 \mathrm{p}$.

KREGEL, J. A. Can we create a stable international financial environment that ensures net resource transfers to developing countries? Journal of Post Keynesian Economics, Armonk, v. 26, n. 4, p. 573-590, 2004.

LACERDA, A. C. Lições para o Brasil no pós-crise. Terra Magazine, 18 Dec. 2009. Available at: < http://terramagazine.terra.com.br/interna/0,,OI4164067-EI7095,00.html>. Accessed June 5, 2014.

LACERDA, A. C.; OLIVEIRA, A. S. Financiamento externo e instabilidade: uma abordagem pós-keynesiana sobre a economia brasileira do período 1999-2008. In: ENCONTRO INTERNACIONAL DA ASSOCIAÇÃO KEYNESIANA BRASILEIRA, 2., 2009, Porto Alegre. Anais... Porto Alegre: Associação Keynesiana Brasileira, 2009. Available at: <http://www. akb.org.br/>. Accessed June 15, 2012.

LOPEZ, J. Mexico's crisis: financial modernization and financial fragility. Quarterly Review (Banca Nazionale del Lavoro), Rome, v. 50, n. 201, p. 165-185, 1997.

MARTINS, R. Fragilidade financeira externa: uma avaliação da economia brasileira no pós-real. 2007. 90 f. Trabalho de Conclusão de Curso de Graduação em Economia. Centro Sócio Econômico, Universidade Federal de Santa Catarina, Florianópolis, 2007.

MINSKY, H. P. Can "it" happen again? Essays on instability and finance. Armonk: M. E. Sharpe Inc., 1982a.

MINSKY, H. P. Estabilizando uma economia instável. São Paulo: Novo Século, 2010. 455 p.

MINSKY, H. P. The financial instability hypothesis: capitalist process and the behavior of the economy. Hyman P. Minsky Archive Paper, n. 282. Annandale-on-Hudson: The Levy Economics Institute of Bard College, $1982 \mathrm{~b}$.

MOLLO, M. L. R. Instabilidade do capitalismo, incerteza e papel das autoridades monetárias: uma leitura de Minsky. Revista de Economia Política, São Paulo, v. 8, n. 1, p. 100-123, 1988.

MUNHOZ, V. C. V.; KOBAYASHI, T. C.; CORREA, V. P. Vulnerabilidade externa no Brasil, Argentina, Chile e México: uma análise empírica da volatilidade dos fluxos financeiros e das fugas de capitais. In: ENCONTRO NACIONAL DE ECONOMIA, 38., 2010, Salvador. Anais... Salvador: Associação Nacional de Pós-Graduação em Economia, 2010. Available at:<http://www.anpec.org.br/encontro2010/inscricao/arquivos/000-059c44ee2d- 
886176dc97ad80560a6517.doc>. Accessed August 27, 2014.

PAULA, L. F. R.; ALVES JR., A. J. Fragilidade financeira externa e os limites da política cambial no real. Revista de Economia Política, São Paulo, v. 19, n. 1, p. 72-93, 1999.

PRATES, D. M.; CUNHA, A. M. Controles de capitais e o perfil do passivo externo brasileiro: tendências recentes e perspectivas. Indicadores Econômicos FEE, Porto Alegre, v. 40, n. 4, p. 71-82, 2013.

PRATES, D. M.; CUNHA, A. M.; LÉLIS, M. T. C. O Brasil e a crise financeira global: avaliando os canais de transmissão nas contas externas. Revista Econômica Contemporânea, Rio de Janeiro, v. 15, n. 1, p. 62-91, 2011.

RESENDE, M. F. C.; AMADO, A. M. Liquidez internacional e ciclo reflexo: algumas observações para a América Latina. Revista de Economia Política, Rio de Janeiro, v. 27, n. 1 p. 41-59, 2007.

SOARES, C. O modelo de balanço de pagamentos restrito e desindustrialização: teoria e evidências para o caso brasileiro. 2012. $170 \mathrm{f}$. Tese de doutorado em Economia. Universidade de Brasília, Brasília, 2012.

TONVERONACHI, M. Foreign debt and financial fragility in the perspective of the emerging countries. Quarterly Review (Banca Nazionale del Lavoro), Rome, v. 58, n. 236, p. 23-48, 2006.

\author{
About the authors \\ Victor Hugo Rocha Sarto - vhrs87@hotmail.com \\ Universidade Estadual Paulista "Júlio de Mesquita Filho" - UNESP, Campus de Araraquara, SP. \\ Luciana Togeiro de Almeida - Itogeiro@fclar.unesp.br \\ Universidade Estadual Paulista "Júlio de Mesquita Filho" - UNESP, Campus de Araraquara, SP.
}

\title{
About the article
}

Submission received on January 04, 2015. Approved for publication on June 21, 2015. 


\section{Appendix}

\section{Appendix A}

Table A1 Data used for calculating external operational fragility measures - US\$ Million

\begin{tabular}{|c|c|c|c|c|c|c|c|c|}
\hline Period & NX & $\mathrm{r}^{\mathrm{FAFA}}$ & UT & $\mathrm{rDFD}^{\mathrm{FD}}$ & MD & $\begin{array}{r}\text { Other } \\
\text { Debts } \\
\text { Financial } \\
\text { Account }\end{array}$ & NFD & $\begin{array}{r}\text { Foreign } \\
\text { Finan- } \\
\text { cing }\end{array}$ \\
\hline 1999 T1 & -1988 & 712 & 479 & 4690 & 23319 & 2159 & 194446 & 20886 \\
\hline 1999 T2 & -1631 & 870 & 415 & 6767 & 18857 & 541 & 201559 & 37216 \\
\hline 1999 T3 & -2052 & 881 & 400 & 4158 & 13692 & 1308 & 206489 & 21120 \\
\hline 1999 T4 & -2505 & 1472 & 395 & 7167 & 22955 & 5190 & 214294 & 27735 \\
\hline $2000 \mathrm{~T} 1$ & -1392 & 1152 & 348 & 4094 & 12875 & 185 & 218280 & 22329 \\
\hline $2000 \mathrm{~T} 2$ & -1014 & 723 & 387 & 7089 & 22741 & 960 & 225273 & 20449 \\
\hline 2000 T3 & -1689 & 952 & 362 & 3990 & 19516 & 3197 & 229637 & 31583 \\
\hline $2000 \mathrm{~T} 4$ & -3765 & 793 & 424 & 6334 & 11827 & 2851 & 238519 & 23349 \\
\hline 2001 T1 & -2530 & 823 & 389 & 5350 & 12927 & 909 & 245187 & 20642 \\
\hline 2001 T2 & -1584 & 1019 & 389 & 6497 & 14947 & 249 & 251860 & 22993 \\
\hline 2001 T3 & -639 & 733 & 406 & 4592 & 10273 & 4790 & 255953 & 22456 \\
\hline $2001 \mathrm{~T} 4$ & -355 & 705 & 453 & 6583 & 14301 & 739 & 261734 & 17754 \\
\hline 2002 T1 & -64 & 885 & 366 & 4435 & 9991 & 803 & 270505 & 15115 \\
\hline $2002 \mathrm{~T} 2$ & 13 & 517 & 557 & 6233 & 17962 & 1864 & 246354 & 24903 \\
\hline 2002 T3 & 4041 & 921 & 699 & 4663 & 14429 & 3377 & 207752 & 16695 \\
\hline 2002 T4 & 4173 & 974 & 768 & 6155 & 14408 & 950 & 227200 & 16544 \\
\hline 2003 T1 & 3045 & 921 & 616 & 4418 & 8587 & 1452 & 233877 & 14118 \\
\hline 2003 T2 & 5127 & 653 & 611 & 5957 & 17303 & 901 & 253825 & 24101 \\
\hline 2003 T3 & 5978 & 903 & 879 & 4445 & 14221 & 1100 & 255282 & 19132 \\
\hline 2003 T4 & 5713 & 862 & 760 & 7071 & 20950 & 5891 & 267509 & 17916 \\
\hline 2004 T1 & 5491 & 760 & 738 & 5352 & 12027 & 1433 & 265478 & 14278 \\
\hline 2004 T2 & 7671 & 779 & 845 & 6555 & 19251 & 1197 & 245244 & 11963 \\
\hline 2004 T3 & 8700 & 674 & 772 & 4854 & 14262 & 8637 & 263323 & 19064 \\
\hline 2004 T4 & 7101 & 986 & 880 & 6959 & 16722 & 3932 & 291607 & 20483 \\
\hline 2005 T1 & 7128 & 750 & 838 & 6060 & 12566 & 1249 & 291515 & 19043 \\
\hline 2005 T2 & 8965 & 859 & 845 & 8076 & 18730 & 410 & 306940 & 19878 \\
\hline 2005 T3 & 10754 & 756 & 916 & 6755 & 32523 & 7067 & 345845 & 30235 \\
\hline 2005 T4 & 9548 & 830 & 959 & 8270 & 39248 & 46 & 309495 & 28999 \\
\hline
\end{tabular}




\begin{tabular}{|c|c|c|c|c|c|c|c|c|}
\hline Period & NX & rAFA $^{\text {FA }}$ & UT & $\mathrm{r}^{\mathrm{FDFD}}$ & MD & $\begin{array}{r}\text { Other } \\
\text { Debts } \\
\text { Financial } \\
\text { Account }\end{array}$ & NFD & $\begin{array}{r}\text { Foreign } \\
\text { Finan- } \\
\text { cing }\end{array}$ \\
\hline $2006 \mathrm{~T} 1$ & 7606 & 1327 & 943 & 8252 & 28568 & 8660 & 345324 & 38716 \\
\hline 2006 T2 & 7730 & 2295 & 1094 & 9970 & 39452 & 2317 & 333489 & 35475 \\
\hline 2006 T3 & 11832 & 1382 & 1175 & 6886 & 22468 & 7009 & 327469 & 31329 \\
\hline 2006 T4 & 9649 & 1457 & 1095 & 8833 & 31917 & 21754 & 360011 & 54307 \\
\hline $2007 \mathrm{~T} 1$ & 6005 & 2013 & 961 & 8738 & 39404 & 3096 & 370027 & 48987 \\
\hline 2007 T2 & 8561 & 2989 & 983 & 10352 & 42735 & 12397 & 427789 & 69677 \\
\hline 2007 T3 & 6940 & 2934 & 1015 & 9763 & 45847 & 5889 & 496520 & 68747 \\
\hline 2007 T4 & 5308 & 3557 & 1071 & 11931 & 67117 & 4043 & 530844 & 90442 \\
\hline $2008 \mathrm{~T} 1$ & -561 & 2934 & 987 & 13620 & 69276 & 4625 & 514654 & 88116 \\
\hline 2008 T2 & 3720 & 3396 & 899 & 14626 & 82857 & 6193 & 615184 & 101934 \\
\hline 2008 T3 & 3565 & 2556 & 985 & 13118 & 85787 & 12591 & 394419 & 108600 \\
\hline 2008 T4 & 1422 & 3626 & 1353 & 11709 & 66075 & 2222 & 275312 & 63452 \\
\hline $2009 \mathrm{~T} 1$ & 150 & 2436 & 862 & 8386 & 40065 & 337 & 305510 & 42371 \\
\hline 2009 T2 & 5643 & 2254 & 802 & 10938 & 49453 & 10778 & 436213 & 63312 \\
\hline 2009 T3 & 1971 & 1900 & 924 & 9679 & 53138 & 4086 & 554002 & 78372 \\
\hline 2009 T4 & -1720 & 2236 & 750 & 13507 & 50289 & 4238 & 608001 & 87128 \\
\hline 2010 T1 & -5045 & 1571 & 769 & 9211 & 33920 & 8669 & 610800 & 54794 \\
\hline 2010 T2 & -606 & 1553 & 794 & 13644 & 39992 & 12303 & 583475 & 64496 \\
\hline 2010 T3 & -3807 & 1910 & 672 & 10308 & 36870 & 12043 & 715625 & 69793 \\
\hline 2010 T4 & -1229 & 2372 & 667 & 13729 & 44778 & 25070 & 936819 & 101420 \\
\hline 2011 T1 & -4573 & 2603 & 892 & 13703 & 39055 & 8906 & 1006177 & 66853 \\
\hline 2011 T2 & -468 & 3155 & 684 & 14633 & 54278 & 16396 & 1041994 & 83103 \\
\hline 2011 T3 & 30 & 2426 & 713 & 13801 & 40335 & 13193 & 797159 & 75086 \\
\hline 2011 T4 & -3128 & 2568 & 696 & 15936 & 39494 & 6764 & 844454 & 61527 \\
\hline 2012 T1 & -6951 & 3008 & 692 & 8813 & 44101 & 1511 & 919072 & 69222 \\
\hline 2012 T2 & -5568 & 4392 & 754 & 12765 & 47689 & 4595 & 751877 & 62756 \\
\hline 2012 T3 & -1243 & 1756 & 673 & 10084 & 41042 & 13362 & 788406 & 66531 \\
\hline 2012 T4 & -7885 & 1732 & 727 & 14673 & 53148 & 13359 & 825637 & 81405 \\
\hline 2013 T1 & -15648 & 1496 & 896 & 11509 & 42787 & 5839 & 871673 & 69079 \\
\hline 2013 T2 & -9420 & 1961 & 645 & 11726 & 77348 & 8117 & 754545 & 100686 \\
\hline 2013 T3 & -11354 & 5248 & 676 & 11683 & 73375 & 18435 & 790551 & 100630 \\
\hline 2013 T4 & -8544 & 1366 & 1147 & 14926 & 76273 & 16599 & 764022 & 101259 \\
\hline
\end{tabular}

Source: Banco Central do Brasil. Self-Elaboration. 


\section{Appendix B}

Table A2 Data used for calculating external structural fragility measures - US\$ Million

\begin{tabular}{|c|c|c|c|c|c|}
\hline Period & STGED & $\begin{array}{r}\text { Reserve As- } \\
\text { sets }\end{array}$ & Period & STGED & $\begin{array}{r}\text { Reserve As- } \\
\text { sets }\end{array}$ \\
\hline 2001 T4 & 174880 & 35866 & $2008 \mathrm{~T} 1$ & 526561 & 195232 \\
\hline 2002 T1 & 181175 & 36721 & 2008 T2 & 602880 & 200827 \\
\hline 2002 T2 & 175135 & 41999 & 2008 T3 & 437297 & 206494 \\
\hline 2002 T3 & 149039 & 38381 & 2008 T4 & 322230 & 193783 \\
\hline 2002 T4 & 155463 & 37823 & 2009 T1 & 338426 & 190388 \\
\hline 2003 T1 & 157242 & 42335 & 2009 T2 & 429940 & 201467 \\
\hline 2003 T2 & 166159 & 47956 & 2009 T3 & 526655 & 221629 \\
\hline 2003 T3 & 168020 & 52675 & 2009 T4 & 593692 & 238520 \\
\hline 2003 T4 & 184287 & 49296 & 2010 T1 & 597745 & 243762 \\
\hline 2004 T1 & 185340 & 51612 & 2010 T2 & 576678 & 253114 \\
\hline 2004 T2 & 171451 & 49805 & 2010 T3 & 695815 & 275206 \\
\hline 2004 T3 & 184381 & 49496 & 2010 T4 & 721247 & 288575 \\
\hline 2004 T4 & 202871 & 52935 & 2011 T1 & 769041 & 317146 \\
\hline 2005 T1 & 214245 & 61960 & $2011 \mathrm{~T} 2$ & 774996 & 335775 \\
\hline 2005 T2 & 209601 & 59885 & 2011 T3 & 626182 & 349708 \\
\hline 2005 T3 & 246544 & 57008 & 2011 T4 & 645231 & 352012 \\
\hline 2005 T4 & 249741 & 53799 & 2012 T1 & 729866 & 365216 \\
\hline 2006 T1 & 283090 & 59824 & 2012 T2 & 626078 & 373910 \\
\hline 2006 T2 & 267416 & 62670 & 2012 T3 & 646738 & 378726 \\
\hline 2006 T3 & 274946 & 73393 & 2012 T4 & 674444 & 373147 \\
\hline 2006 T4 & 322822 & 85839 & 2013 T1 & 687978 & 376934 \\
\hline 2007 T1 & 352048 & 109531 & 2013 T2 & 596682 & 369402 \\
\hline 2007 T2 & 434251 & 147101 & 2013 T3 & 644806 & 368654 \\
\hline 2007 T3 & 500455 & 162962 & 2013 T4 & 616574 & 358808 \\
\hline 2007 T4 & 542718 & 180334 & & & \\
\hline
\end{tabular}

Source: Banco Central do Brasil. Self-Elaboration. 


\section{Appendix C}

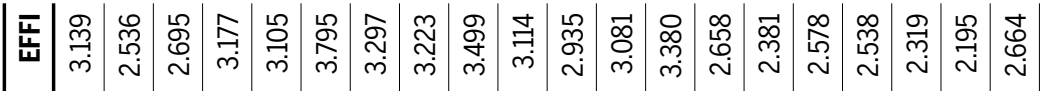

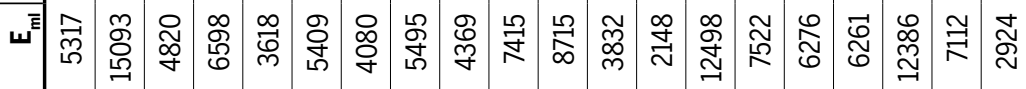

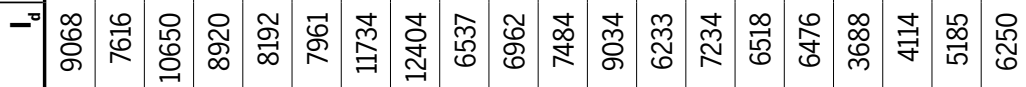

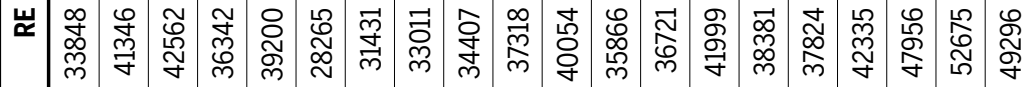

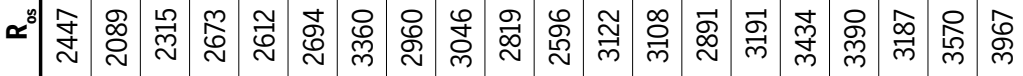

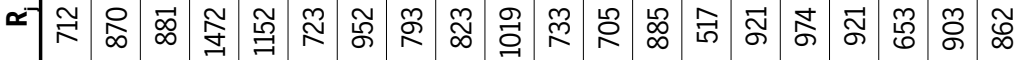

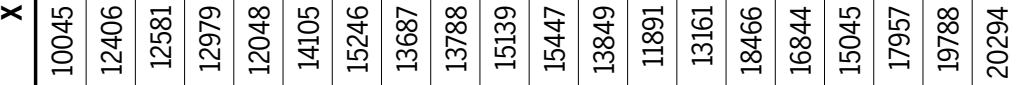

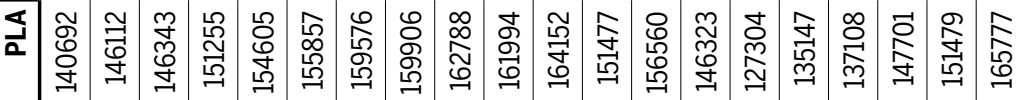

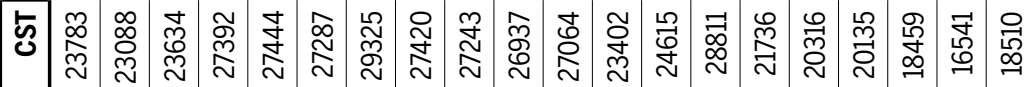

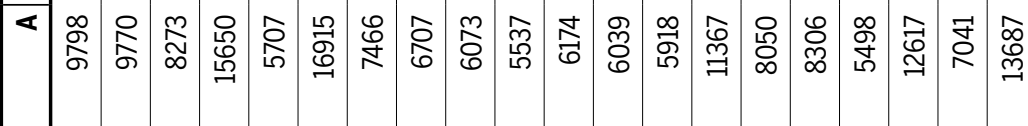

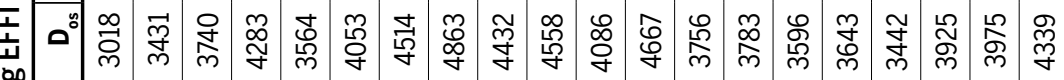

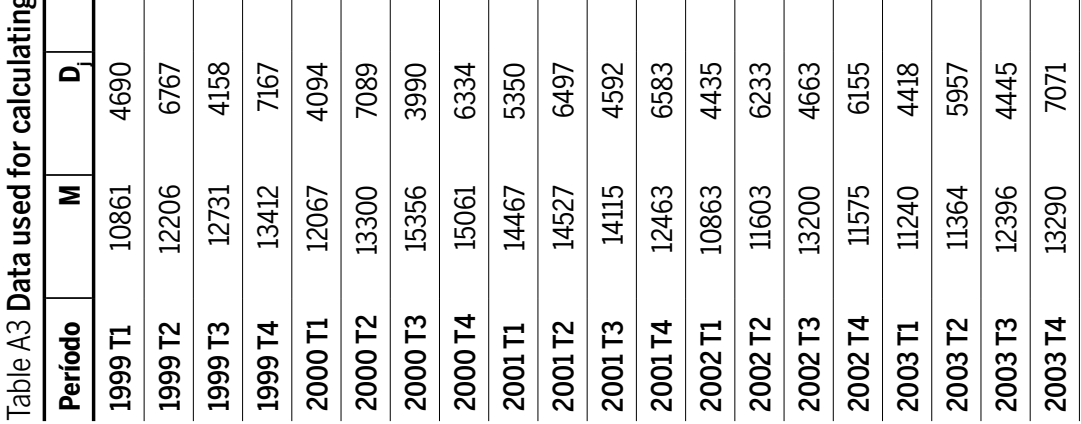




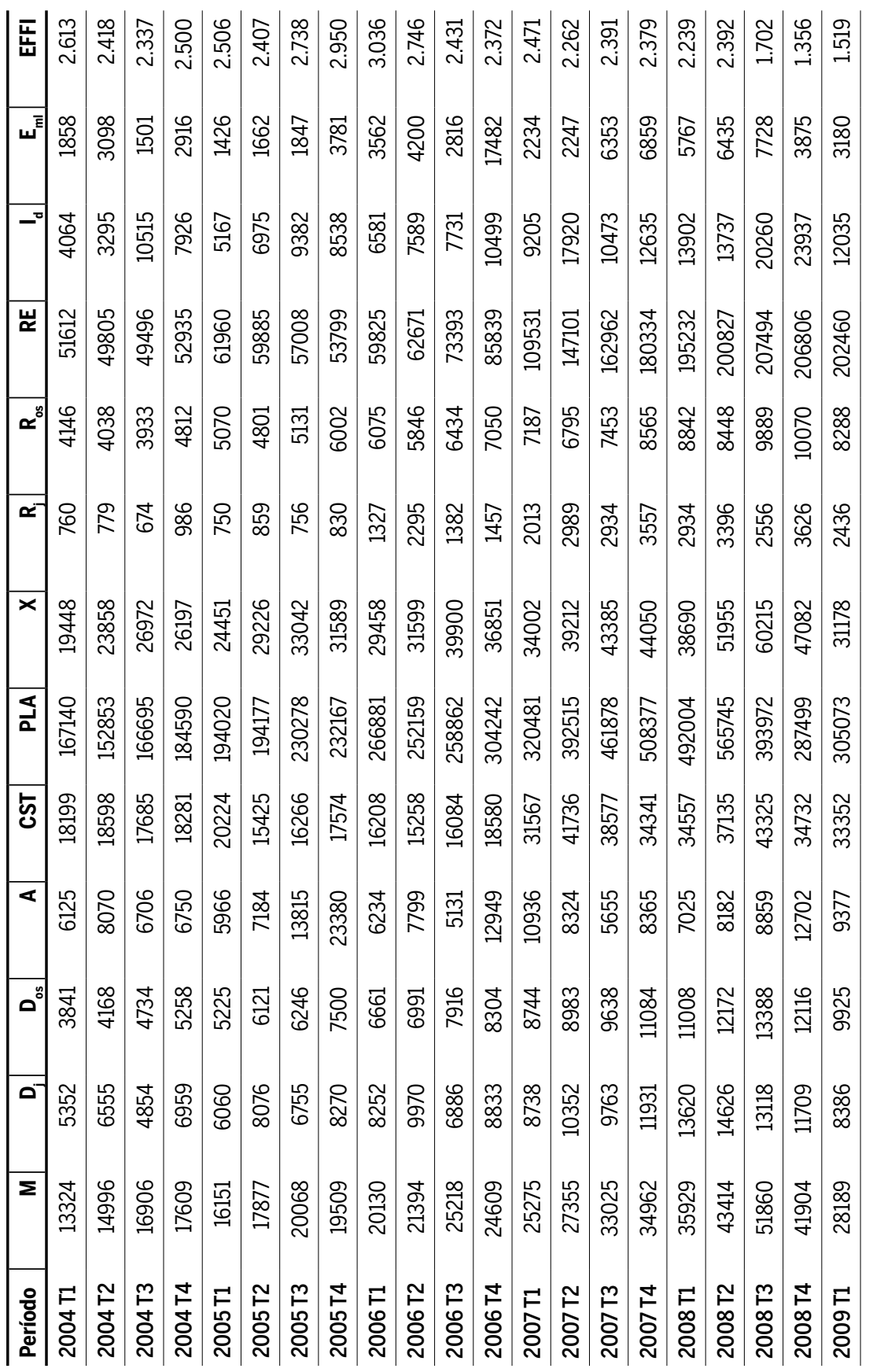




\begin{tabular}{|c|c|c|c|c|c|c|c|c|c|c|c|c|c|c|c|c|c|c|c|}
\hline 豈 & 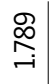 & ָ̃ & 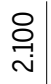 & 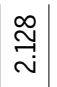 & $\begin{array}{l}\widetilde{\mathscr{~}} \\
\stackrel{-}{-}\end{array}$ & $\stackrel{\substack{m \\
\sim}}{\sim}$ & $\begin{array}{l}\stackrel{\sim}{\sim} \\
\stackrel{\sim}{\sim}\end{array}$ & $\begin{array}{l}\vec{\sigma} \\
\stackrel{\sim}{*}\end{array}$ & 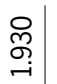 & $\begin{array}{l}\text { ్ָరి } \\
\text { గ్ర }\end{array}$ & $\underset{\vec{G}}{\stackrel{\sigma}{-1}}$ & $\underset{-}{\stackrel{F}{F}}$ & $\begin{array}{l}\underset{\sim}{n} \\
\text { గi }\end{array}$ & 茵 & 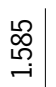 & $\begin{array}{l}\vec{\infty} \\
\stackrel{\leftrightarrow}{-}\end{array}$ & $\stackrel{\infty}{\underset{\sim}{\sim}}$ & 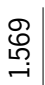 & $\underset{-}{\stackrel{f}{\Im}}$ \\
\hline$\omega^{\bar{E}}$ & ஜֶष & 옹 & 宊 & 守 & $\underset{\infty}{\stackrel{\aleph}{\approx}}$ & 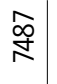 & 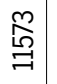 & $\begin{array}{l}\text { o } \\
\text { 음 }\end{array}$ & $\underset{\mathscr{ల}}{\mathscr{\varphi}}$ & 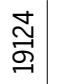 & 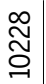 & $\begin{array}{l}\mathscr{D} \\
\stackrel{N}{N}\end{array}$ & 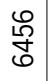 & $\underset{\infty}{\stackrel{\infty}{\not}}$ & $\begin{array}{l}\underset{8}{ } \\
\stackrel{\infty}{\Xi}\end{array}$ & 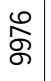 & $\stackrel{\infty}{\infty}$ & $\begin{array}{l}\widetilde{\infty} \\
\underset{G}{G}\end{array}$ & 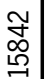 \\
\hline-0 & $\underset{\overparen{\Im}}{\stackrel{\Im}{\exists}}$ & $\underset{\sim}{\stackrel{\Xi}{\sim}}$ & $\begin{array}{l}\stackrel{\sigma}{\sigma} \\
\stackrel{\sigma}{\sigma}\end{array}$ & ণ্ণি & 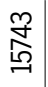 & \begin{tabular}{l}
$\infty$ \\
$\stackrel{\infty}{\infty}$ \\
$\infty$ \\
$\infty$ \\
\hdashline
\end{tabular} & 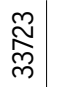 & 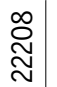 & 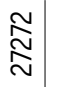 & $\begin{array}{l}\infty \\
\stackrel{\infty}{\infty} \\
\infty \\
\sim\end{array}$ & 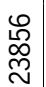 & 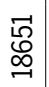 & $\stackrel{\text { 묭 }}{\text { 马 }}$ & 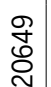 & $\begin{array}{l}\overrightarrow{\mathrm{F}} \\
\stackrel{\leftrightarrow}{\sim}\end{array}$ & 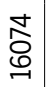 & $\begin{array}{l}\text { ठั } \\
\text { 음 }\end{array}$ & $\begin{array}{l}\infty \\
\text { Оి } \\
\stackrel{\leftrightarrow}{\sigma}\end{array}$ & $\begin{array}{l}\vec{m} \\
\stackrel{\infty}{\sim}\end{array}$ \\
\hline 山् & $\begin{array}{l}\stackrel{\sim}{\sim} \\
\stackrel{\infty}{0} \\
\stackrel{\sim}{\sim}\end{array}$ & 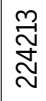 & $\begin{array}{l}\text { 芩 } \\
\text { О } \\
\text { N }\end{array}$ & 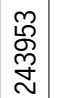 & $\begin{array}{l}\underset{7}{ت} \\
\stackrel{\sim}{\sim}\end{array}$ & 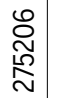 & 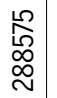 & 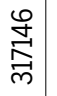 & $\begin{array}{c}\stackrel{e}{\kappa} \\
\stackrel{m}{m} \\
m\end{array}$ & $\begin{array}{l}\infty \\
\stackrel{0}{9} \\
\stackrel{9}{+}\end{array}$ & 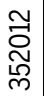 & 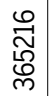 & $\begin{array}{l}\stackrel{\circ}{\circ} \\
\stackrel{m}{m} \\
\stackrel{m}{m}\end{array}$ & $\begin{array}{l}\stackrel{0}{\mathbb{N}} \\
\underset{m}{\infty}\end{array}$ & $\begin{array}{l}\checkmark \\
\stackrel{D}{ } \\
\stackrel{\infty}{m}\end{array}$ & 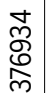 & 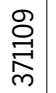 & $\begin{array}{l}\text { 우 } \\
\text { 이 }\end{array}$ & $\begin{array}{l}\text { के } \\
\text { م. } \\
\text { m }\end{array}$ \\
\hline$\propto^{n}$ & 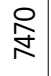 & 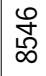 & $\begin{array}{l}\infty \\
\infty \\
ٌ ٌ\end{array}$ & ర్ర & ষ্ঠ & $\begin{array}{l}\widetilde{\infty} \\
\infty \\
\infty\end{array}$ & ஜூ & $\begin{array}{l}0 \\
\mathscr{0} \\
0 \\
0\end{array}$ & $\begin{array}{l}\stackrel{2}{0} \\
\stackrel{0}{0}\end{array}$ & 号 & $\overrightarrow{\tilde{D}}$ & 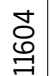 & $\stackrel{\infty}{\stackrel{\infty}{\exists}}$ & $\underset{\Xi}{\Xi}$ & $\stackrel{\text { ஜ }}{\infty}$ & 全 & 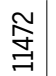 & 守 & $\stackrel{\stackrel{\sim}{\sim}}{\underset{\exists}{\Im}}$ \\
\hline$\alpha$ & 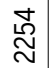 & 용 & $\underset{\varpi}{\approx}$ & $\overrightarrow{\widehat{S}}$ & 营 & 음 & $\underset{\sim}{\mathbb{N}}$ & 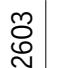 & $\begin{array}{l}\stackrel{\llcorner}{\llcorner} \\
\stackrel{m}{m}\end{array}$ & $\underset{\stackrel{\sim}{\sim}}{\stackrel{\sim}{\sim}}$ & 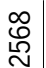 & $\stackrel{\infty}{\circ}$ & $\underset{\sim}{\text { ণ্ }}$ & $\begin{array}{l}0 \\
\stackrel{D}{-1}\end{array}$ & $\stackrel{\widetilde{\Xi}}{\Xi}$ & $\underset{\mathscr{O}}{\mathscr{O}}$ & 뭄 & $\underset{\substack{\sim\\
}}{ }$ & $\begin{array}{l}\mathscr{Q} \\
\text { ల్య }\end{array}$ \\
\hline$x$ & 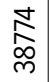 & 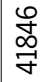 & 荨 & ণ্ণি & 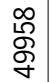 & 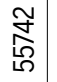 & $\begin{array}{l}0 \\
0 \\
\mathscr{8} \\
\llcorner\end{array}$ & 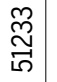 & \begin{tabular}{l}
\multirow{2}{\circ}{} \\
ô
\end{tabular} & $\begin{array}{l}\stackrel{\llcorner}{8} \\
\stackrel{N}{\pi}\end{array}$ & $\begin{array}{l}\vec{\forall} \\
\text { ठ্ট }\end{array}$ & 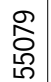 & 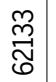 & $\begin{array}{l}m \\
\infty \\
\text { } \\
\tilde{\sigma}\end{array}$ & 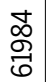 & 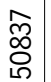 & 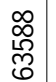 & 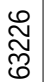 & 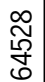 \\
\hline 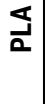 & 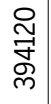 & ষ্ণ & $\begin{array}{l}\text { 잉 } \\
\mathbb{0} \\
\stackrel{\sim}{n}\end{array}$ & $\begin{array}{l}\vec{\sigma} \\
0 \\
0 \\
\llcorner \\
0\end{array}$ & $\begin{array}{l}\text { ల్ } \\
\text { ల్ } \\
\text { గn }\end{array}$ & \begin{tabular}{l}
$\hat{ల}$ \\
Oे \\
\multirow{0}{*}{}
\end{tabular} & 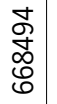 & $\begin{array}{l}\widetilde{\sigma} \\
\vec{్} \\
\stackrel{\nabla}{1}\end{array}$ & 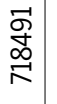 & $\underset{\text { 욜 }}{\stackrel{ }{\mathbb{N}}}$ & 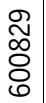 & $\begin{array}{l}\mathscr{D} \\
0 \\
0 \\
0 \\
0\end{array}$ & 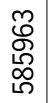 & 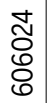 & $\begin{array}{l}\stackrel{\nabla}{ } \\
\infty \\
\widetilde{్}\end{array}$ & $\begin{array}{l}\vec{D} \\
\infty \\
\infty \\
\widetilde{0}\end{array}$ & $\begin{array}{l}\infty \\
\stackrel{\infty}{\infty} \\
\infty \\
\stackrel{\sim}{\circ}\end{array}$ & 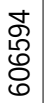 & 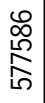 \\
\hline 式 & $\begin{array}{l}\stackrel{8}{\infty} \\
\infty \\
\stackrel{్}{m}\end{array}$ & 공 & $\begin{array}{l}\text { Oे } \\
\text { Oे } \\
\text { m }\end{array}$ & 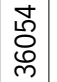 & 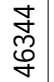 & 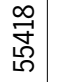 & 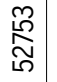 & 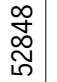 & $\begin{array}{l}\text { 노 } \\
\text { 윰 } \\
\llcorner\end{array}$ & 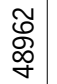 & 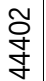 & $\underset{\infty}{\stackrel{-}{F}}$ & 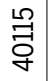 & 寺 & $\begin{array}{l}\text { 유 } \\
\text { 心్ } \\
\stackrel{m}{n}\end{array}$ & $\underset{\widetilde{\sigma}}{\stackrel{\Im}{\sigma}}$ & $\underset{m}{\frac{N}{m}}$ & 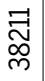 & $\begin{array}{l}\infty \\
\infty \\
\infty \\
\infty \\
m\end{array}$ \\
\hline$<$ & $\underset{\infty}{\vec{\infty}}$ & 용 & 芯 & $\begin{array}{l}\vec{\sigma} \\
\stackrel{\infty}{ }\end{array}$ & $\begin{array}{l}\stackrel{\infty}{+} \\
\stackrel{m}{m}\end{array}$ & 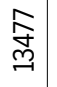 & $\underset{\widetilde{\Xi}}{\widetilde{\Xi}}$ & $\begin{array}{l}\text { ᄋ్ } \\
\text { О } \\
\end{array}$ & 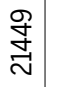 & $\begin{array}{l}\overrightarrow{\tilde{N}} \\
\underline{్}\end{array}$ & 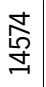 & ஓ্. & 导 & $\begin{array}{l}0 \\
\text { 옹 } \\
\infty\end{array}$ & $\begin{array}{l}\stackrel{8}{2} \\
\stackrel{\infty}{\sigma}\end{array}$ & $\begin{array}{l}\text { 寸 } \\
\varnothing \\
\infty\end{array}$ & $\begin{array}{l}\stackrel{m}{\approx} \\
\stackrel{\infty}{=}\end{array}$ & 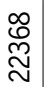 & 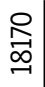 \\
\hline $0^{\ddot{0}}$ & $\stackrel{す}{す}$ & 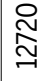 & 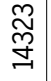 & $\stackrel{\stackrel{\sim}{\widetilde{Z}}}{\underset{\Xi}{\exists}}$ & 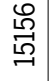 & $\begin{array}{l}\mathbb{Z} \\
0 \\
6\end{array}$ & $\begin{array}{l}\infty \\
\infty \\
\infty \\
0\end{array}$ & $\begin{array}{l}\hat{m} \\
\stackrel{\Xi}{=}\end{array}$ & 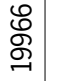 & 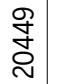 & 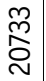 & $\begin{array}{l}\infty \\
\text { ᄋ } \\
\text { の }\end{array}$ & 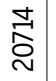 & $\begin{array}{l}2 \\
0 \\
\mathscr{D} \\
\tilde{N}\end{array} \mid$ & 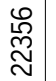 & $\begin{array}{l}\text { 승 } \\
\text { ㄱ. }\end{array}$ & 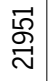 & $\underset{\mathbb{N}}{\stackrel{\mathbb{N}}{ \pm}}$ & $\underset{\sim}{\sim}$ \\
\hline - & \begin{tabular}{l}
$\infty$ \\
$\dddot{O}$ \\
\hdashline
\end{tabular} & $\frac{9}{8}$ & 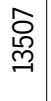 & নี & \begin{tabular}{l}
\multirow{Z}{*}{} \\
m్
\end{tabular} & $\begin{array}{l}\infty \\
0 \\
\text { Oల] }\end{array}$ & 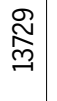 & $\begin{array}{l}\stackrel{m}{p} \\
\text { m }\end{array}$ & 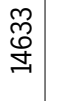 & 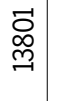 & 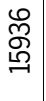 & $\begin{array}{c}m \\
\infty \\
\infty\end{array}$ & $\begin{array}{l}\stackrel{L}{ٍ} \\
\stackrel{(}{\nearrow}\end{array}$ & $\begin{array}{l} \\
0 \\
0 \\
0 \\
\end{array}$ & 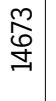 & $\begin{array}{l}\text { 음 } \\
\text { 임 }\end{array}$ & 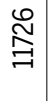 & \begin{tabular}{l}
$\mathscr{m}$ \\
0 \\
$\mathscr{G}$ \\
\hdashline
\end{tabular} & 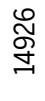 \\
\hline$\Sigma$ & $\begin{array}{l}\stackrel{ \pm}{\infty} \\
\stackrel{\infty}{\lesssim}\end{array}$ & 筩 & $\begin{array}{l}\stackrel{P}{\circ} \\
\text { }\end{array}$ & $\mid \begin{array}{c}\text { P } \\
\text { } \\
\stackrel{m}{m}\end{array}$ & 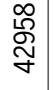 & $\begin{array}{l}\hat{\tilde{D}} \\
\text { Оి }\end{array}$ & 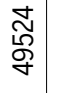 & $\begin{array}{l}\vec{\delta} \\
\text { \& }\end{array}$ & 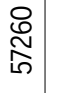 & $\begin{array}{l}\infty \\
\stackrel{0}{0} \\
\sigma\end{array}$ & 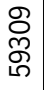 & $\mid \begin{array}{l}\vec{\sigma} \\
\tilde{N} \\
\tilde{N}\end{array}$ & 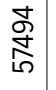 & 肙 & $\begin{array}{l}\underset{\infty}{\infty} \\
\text { D) }\end{array}$ & 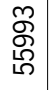 & $\begin{array}{l}\mathscr{0} \\
\stackrel{0}{0} \\
\sigma\end{array}$ & $\begin{array}{l}\vec{b} \\
\vec{b}\end{array}$ & $\begin{array}{l}\text { 유 } \\
\text { ర్రి }\end{array}$ \\
\hline 융 & $\begin{array}{l}\tilde{N} \\
\stackrel{2}{\circ} \\
\stackrel{\sim}{*}\end{array}$ & 孞 & \begin{tabular}{l}
\multirow{+}{*}{} \\
$\stackrel{2}{\circ}$ \\
$\stackrel{N}{2}$
\end{tabular} & $\begin{array}{l}F \\
\text { O } \\
\text { D }\end{array}$ & $\begin{array}{l}\mathfrak{} \\
\text { 음 } \\
\text { N }\end{array}$ & 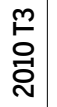 & 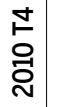 & $\begin{array}{l}\vec{E} \\
\underset{\sim}{二}\end{array}$ & $\begin{array}{l}\tilde{E} \\
\vec{D} \\
\stackrel{\sim}{N}\end{array}$ & 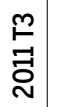 & 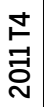 & $\begin{array}{l}\vec{I} \\
\underset{\sim}{\Xi} \\
\stackrel{\sim}{N}\end{array}$ & $\begin{array}{l}\stackrel{\sim}{\mathfrak{N}} \\
\stackrel{\sim}{\sim}\end{array}$ & $\begin{array}{l}\stackrel{m}{\mathfrak{Z}} \\
\stackrel{\sim}{D}\end{array}$ & 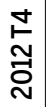 & $\begin{array}{l}\vec{E} \\
m \\
\stackrel{D}{D}\end{array}$ & 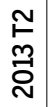 & $\begin{array}{l}\stackrel{m}{m} \\
\stackrel{\sim}{\sim}\end{array}$ & 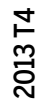 \\
\hline
\end{tabular}




\section{Appendix D}

Table A4 Data used for calculating Current EF

\begin{tabular}{|c|c|c|c|}
\hline Period & $\begin{array}{r}\sum \text { DECME } \\
\text { (US\$ Million) }\end{array}$ & $\begin{array}{r}\sum \text { DICME } \\
\text { (US\$ Million) }\end{array}$ & $\begin{array}{r}\text { Current EFFI = } \\
\sum \text { DECME } / \sum \text { DICM }\end{array}$ \\
\hline $1998 \mathrm{~T} 4$ & 48441 & 54800 & 0.884 \\
\hline 1999 T1 & 46314 & 36936 & 1.254 \\
\hline 1999 T2 & 42641 & 54110 & 0.788 \\
\hline 1999 T3 & 35048 & 37297 & 0.940 \\
\hline 1999 T4 & 49948 & 45658 & 1.094 \\
\hline 2000 T1 & 33903 & 38495 & 0.881 \\
\hline 2000 T2 & 48217 & 38278 & 1.260 \\
\hline 2000 T3 & 48713 & 53388 & 0.912 \\
\hline 2000 T4 & 39775 & 41765 & 0.952 \\
\hline 2001 T1 & 39199 & 39486 & 0.993 \\
\hline 2001 T2 & 42777 & 46007 & 0.930 \\
\hline 2001 T3 & 35333 & 42247 & 0.836 \\
\hline 2001 T4 & 40559 & 40372 & 1.005 \\
\hline 2002 T1 & 31296 & 31909 & 0.981 \\
\hline 2002 T2 & 41491 & 42436 & 0.978 \\
\hline 2002 T3 & 39101 & 40393 & 0.968 \\
\hline 2002 T4 & 37564 & 38902 & 0.966 \\
\hline 2003 T1 & 29503 & 34152 & 0.864 \\
\hline 2003 T2 & 40210 & 47616 & 0.845 \\
\hline 2003 T3 & 36971 & 45382 & 0.815 \\
\hline 2003 T4 & 47311 & 44478 & 1.064 \\
\hline 2004 T1 & 36383 & 39856 & 0.913 \\
\hline 2004 T2 & 47830 & 41910 & 1.141 \\
\hline 2004 T3 & 51663 & 52973 & 0.975 \\
\hline 2004 T4 & 50340 & 54668 & 0.921 \\
\hline 2005 T1 & 43257 & 51405 & 0.842 \\
\hline 2005 T2 & 54674 & 56070 & 0.975 \\
\hline 2005 T3 & 68523 & 70511 & 0.972 \\
\hline 2005 T4 & 77806 & 69662 & 1.117 \\
\hline 2006 T1 & 69695 & 77722 & 0.897 \\
\hline 2006 T2 & 82654 & 78237 & 1.057 \\
\hline 2006 T3 & 69643 & 81013 & 0.860 \\
\hline
\end{tabular}




\begin{tabular}{|c|c|c|c|}
\hline Period & $\begin{array}{r}\sum \text { DECME } \\
\text { (US\$ Million) }\end{array}$ & $\begin{array}{r}\sum \text { DICME } \\
\text { (US\$ Million) }\end{array}$ & $\begin{array}{r}\text { Current EFFI = } \\
\sum \text { DECME } / \sum \text { DICM }\end{array}$ \\
\hline 2006 T4 & 97855 & 101020 & 0.969 \\
\hline 2007 T1 & 89587 & 100921 & 0.888 \\
\hline 2007 T2 & 93753 & 124484 & 0.753 \\
\hline 2007 T3 & 107145 & 130062 & 0.824 \\
\hline 2007 T4 & 144758 & 155081 & 0.933 \\
\hline 2008 T1 & 139477 & 142108 & 0.982 \\
\hline 2008 T2 & 162960 & 170993 & 0.953 \\
\hline 2008 T3 & 178205 & 187526 & 0.950 \\
\hline 2008 T4 & 142613 & 131452 & 1.085 \\
\hline 2009 T1 & 90246 & 89085 & 1.013 \\
\hline 2009 T2 & 108041 & 119875 & 0.901 \\
\hline 2009 T3 & 111212 & 138663 & 0.802 \\
\hline 2009 T4 & 120262 & 155283 & 0.775 \\
\hline 2010 T1 & 107750 & 109700 & 0.982 \\
\hline 2010 T2 & 121144 & 132075 & 0.917 \\
\hline 2010 T3 & 122742 & 146641 & 0.837 \\
\hline 2010 T4 & 148285 & 182613 & 0.812 \\
\hline $2011 \mathrm{T1}$ & 135067 & 158818 & 0.851 \\
\hline 2011 T2 & 154976 & 177666 & 0.872 \\
\hline 2011 T3 & 141319 & 168614 & 0.838 \\
\hline 2011 T4 & 143965 & 151522 & 0.950 \\
\hline 2012 T1 & 135828 & 149123 & 0.911 \\
\hline 2012 T2 & 147479 & 149541 & 0.986 \\
\hline 2012 T3 & 135915 & 143165 & 0.949 \\
\hline 2012 T4 & 157783 & 167054 & 0.945 \\
\hline 2013 T1 & 141957 & 139593 & 1.017 \\
\hline 2013 T2 & 187392 & 199152 & 0.941 \\
\hline 2013 T3 & 181556 & 185160 & 0.981 \\
\hline 2013 T4 & 182731 & 186411 & 0.980 \\
\hline
\end{tabular}

Source: Banco Central do Brasil. Self-Elaboration. 